\title{
Artigo Original / Original Paper \\ Caesalpinioideae e Cercidoideae (Leguminosae) no Parque Estadual Mata da Pimenteira, Semiárido de Pernambuco, Brasil
}

\author{
Caesalpinioideae and Cercidoideae (Leguminosae) in the State Park of Mata da Pimenteira, \\ Semiarid of Pernambuco, Brazil
}

Samara Silva de Matos ${ }^{1}$, André Laurênio de Melo $^{2}$ \& Juliana Santos-Silva ${ }^{1,3}$

\begin{abstract}
Resumo
Este trabalho apresenta um estudo taxonômico das subfamílias Caesalpinioideae (exceto clado Mimosoide) e Cercidoideae, realizado no Parque Estadual Mata da Pimenteira, localizado no município de Serra Talhada, em Pernambuco. Foram analisados espécimes coletados mensalmente, no período compreendido entre março de 2015 a agosto de 2016. Foram catalogadas 16 espécies distribuídas em um gênero de Cercidoideae, com uma espécie: Bauhinia cheilantha, e seis gêneros de Caesalpinioideae, com 15 espécies: Cenostigma pyramidale, Chamaecrista absus, C. duckeana, C. pilosa var. luxurians, C. rotundifolia, C. supplex, Libidibia ferrea, Parkinsonia aculeata, Pterogyne nitens, Senna macranthera, S. obtusifolia, S. occidentalis, S. spectabilis, S. splendida e $S$. uniflora. São apresentadas chaves de identificação, descrições, ilustrações, comentários sobre a morfologia e distribuição geográfica de todas espécies.

Palavras-chave: Caatinga, Fabaceae, flora, semiárido, taxonomia vegetal.

Abstract

This work presents a taxonomic study of the subfamilies Caesalpinioideae (except Mimosoid clade) and Cercidoideae carried out in the State Park of Mata da Pimenteira, located in the municipality of Serra Talhada, in Pernambuco. Specimens were collected monthly in the period from March 2015 to August 2016. A total of 16 species distributed in one genus of Cercidoideae, one species: Bauhinia cheilantha, and six genera in Caesalpinioideae, 15 species: Cenostigma pyramidale, Chamaecrista absus, C. duckeana, C. pilosa var. luxurians, C. rotundifolia, C. supplex, Libidibia ferrea, Parkinsonia aculeata, Pterogyne nitens, Senna macranthera, S. obtusifolia, S. occidentalis, S. spectabilis, S. splendida, and S. uniflora. Identification keys, descriptions, illustrations, comments on the morphology and geographical distribution are presented.
\end{abstract}

Key words: Caatinga, Fabaceae, flora, semiarid, plant taxonomy.

\section{Introdução}

Leguminosae Juss. abrange cerca de 760 gêneros e 19.500 espécies, distribuição cosmopolita e é a terceira maior família de Angiospermas (Lewis et al. 2005). No Brasil, são encontrados aproximadamente 2.750 táxons disseminados em todos tipos vegetacionais (BFG 2018). Possui grande valor agroeconômico, relacionado à indústria alimentícia, estimulada pela produção e consumo de ervilha, feijão, soja, entre outras plantas (Lewis et al. 2005; Wojciechowski 2003; Wojciechowski et al. 2004).

Até recentemente, as suas espécies estavam reunidas em três subfamílias, Caesalpinioideae DC., Mimosoideae DC. e Papilionoideae DC. (Bentham 1859; Lewis et al. 2005; Polhill et al. 1981). Entretanto, análises filogenéticas evidenciavam o parafiletismo de Caesalpinoideae,

\footnotetext{
${ }^{1}$ Universidade do Estado da Bahia, Depto. Educação, Prog. Pós-graduação em Biodiversidade Vegetal, Campus VIII, R. do Gangorra 503, Alves de Souza, 48608-240, Paulo Afonso, BA, Brasil.

${ }^{2}$ Universidade Federal Rural de Pernambuco, Unidade Acadêmica de Serra Talhada, Fazenda Saco s/n, C.P. 063, 56900-000, Serra Talhada, PE, Brasil.

${ }^{3}$ Autor para correspondência: jussilva@uneb.br
} 
que apresentava grupos relacionados tanto a Mimosoideae, quanto a Papilionoideae (Doyle et al. 2000; Gagnon et al. 2016). Desta forma, uma nova classificação com base em dados moleculares foi proposta pelo LPWG (2017), o qual reconheceu seis subfamílias: Cercidoideae LPWG, Detarioideae Burmeist. emend. LPWG, Duparquetioideae LPWG, Dialioideae LPWG, Papilionoideae DC. e Caesalpinioideae DC. emend. LPWG (LPWG 2017).

As quatro primeiras subfamílias foram segregadas de Caesalpinioideae, enquanto os táxons de Mimosoideae estão reunidos no clado Mimosoide. Uma nova circunscrição para Caesalpinioideae é apresentada e atualmente são reconhecidos 148 gêneros e cerca de 4.400 espécies com distribuição pantropical, presentes em locais temperados e regiões secas e úmidas (LPWG 2017). Suas espécies possuem hábitos variados, árvores, arbustos, subarbustos, lianas e ervas, ocasionalmente aquáticas. No geral, podem ser diferenciadas pelas folhas comumente bipinadas, nectários extraflorais (quando presentes) no pecíolo e/ou na raque entre os pares de folíolos, estípulas laterais não intrapeciolares, sementes com um pleurograma aberto ou fechado em cada lado e nódulos radiculares ocasionalmente presentes (LPWG 2017).

Cercidoideae possui aproximadamente 12 gêneros e 335 espécies com distribuição na região pantropical. Seus representantes podem ser arbóreos, arbustivos ou lianescentes, com folhas uni ou bifolioladas, quando unifoliolada a lâmina foliar é inteira ou bilobada, mucronada no ápice ou entre os lobos. As sementes possuem hilo circular (LPWG 2017).

A Caatinga possui cerca de 4.650 espécies, das quais 913 são endêmicas e Leguminosae destaca-se como a família mais representativa com 605 espécies (BFG 2018). As subfamílias Caesalpinioideae (94 spp./21 gêneros) e Cercidoideae (16 spp./dois gêneros) são bem representadas na Caatinga (Queiroz 2009). Entretanto, há poucos estudos exclusivos com estes táxons em sua área de abrangência (Queiroz 2009; Queiroz \& Loiola 2009).

O Parque Estadual Mata da Pimenteira (PEMP), localizado no município de Serra Talhada, é a primeira unidade de conservação em uma área de Caatinga do Estado de Pernambuco. A flora do PEMP tem sido pobremente estudada, tanto do ponto de vista florístico quanto taxonômico, até o momento, nenhum trabalho sobre a taxonomia de grupos de plantas foi realizado, existindo apenas uma listagem florística preliminar (Melo et al. 2013; Farias et al. 2016), onde foram registradas 251 espécies, distribuídas em 180 gêneros e 67 famílias. A família Leguminosae destaca-se por ser a mais diversa e representativa do Parque, com 33 espécies pertencentes a 15 gêneros (Melo et al. 2013).

Diante do escasso conhecimento sobre a flora do PEMP e por Leguminosae ser um grupo diverso e ecologicamente importante no semiárido nordestino, o presente estudo teve como objetivo realizar um tratamento taxonômico das subfamílias Caesalpinioideae (exceto clado Mimosoide) e Cercidoideae, visando contribuir para o conhecimento da flora local e para a elaboração de propostas de conservação do bioma Caatinga.

\section{Material e Métodos}

Área de estudo

O Parque Estadual Mata da Pimenteira, situado no semiárido pernambucano, localizase no município de Serra Talhada (7 $53^{\prime} 49^{\prime}$ 'S, $38^{\circ} 18^{\prime} 14^{\prime \prime} \mathrm{W}$ ) e compreende 887,24 ha (Santos et al. 2013). O clima é do tipo BSWh' (Köppen 1948), quente e seco, com temperatura média em torno $23,8 \pm 0,92{ }^{\circ} \mathrm{C}$ e nível pluviométrico anual baixo (653,2 $\mathrm{mm}$ ) (Silva \& Almeida 2013). A altitude varia de 500-820 m e a vegetação na área é de Caatinga que varia de arbórea a arbustivaarbórea, até herbácea quando sobre afloramentos rochosos (Melo et al. 2013).

\section{Tratamento taxonômico}

De março de 2015 a agosto de 2016 foram realizadas coletas em diferentes localidades do PEMP e da zona de amortecimento, segundo a metodologia sugerida por Mori et al. (1989). Após o processamento do material coletado, toda a coleção foi depositada no HESBRA e duplicatas doadas ao Herbário da Universidade Estadual da Bahia (HUNEB, Coleção Caetité), acrônimo de acordo com Thiers (continuamente atualizado). Outras exsicatas pertencentes ao acervo dos herbários HESBRA, IPA, PEUFR e UFP foram analisadas e inseridas como material adicional a fim de complementar as descrições e as ilustrações, quando existem poucos espécimes coletados para a área e estes se encontravam sem flores ou frutos. A identificação dos táxons foi realizada com base em chaves de identificação em 
obras especializadas (Bentham 1870; Lewis 1987; Queiroz 2009), protólogos e por comparação com imagens de coleções-tipo consultadas virtualmente nos sitios do The New York Botanical Garden, Muséum national d'histoire naturelle, Missouri Botanical Garden e Royal Botanic Gardens. A terminologia dos caracteres morfológicos baseou-se em Radford et al. (1974) e Simpson (2006), para a forma dos nectários em Melo et al. (2010) e dos frutos em Barroso et al. (1999). Informações sobre a distribuição geográfica dos táxons foram obtidas nos trabalhos supracitados, sobretudo em Irwin \& Barneby (1982), Vaz \& Tozzi (2003), Lewis et al. (2005), Queiroz (2009), Gagnon et al. (2016) e no sitio da Flora do Brasil, bem como na observação das espécies no PEMP, enquanto os dados de floração e de frutificação foram verificados nas etiquetas dos espécimes analisados e as descrições dos gêneros apresentadas se baseiam nas espécies tradas para a área de estudo.

\section{Resultados e Discussão}

Foram registrados sete gêneros (Fig. 1) e 16 espécies de Caesalpinioideae e Cercidoideae no Parque Estadual Mata da Pimenteira, dados que aumentam consideravelmente o número de espécies conhecidas para o local (três gêneros, nove espécies - segundo Melo et al. 2013). Bauhinia cheilantha (Bong.) Steud. foi a única espécie encontrada da subfamília Cercidoideae e Caesalpinioideae foi a subfamília mais representativa com seis gêneros e 15 espécies. Senna Mill. com seis espécies é o gênero com maior riqueza, seguido por Chamaecrista Moench com cinco, enquanto Cenostigma Tul., Libidibia (DC.) Schltdl., Parkinsonia L. e Pterogyne Tul. apresentaram apenas uma espécie. Das espécies registradas três são endêmicas do Brasil, Cenostigma pyramidale (Tul.) E. Gagnon \& G.P. Lewis, Chamaecrista duckeana (P. Bezerra \& Afr. Fern.) H.S. Irwin \& Barneby e Chamaecrista pilosa var. luxurians (Benth.) H.S. Irwin \& Barneby (BFG 2018).

A maioria das espécies apresenta ampla ocorrência no PEMP, entretanto algumas são encontradas em locais mais restritos tanto em áreas preservadas quanto em ambientes regenerantes, em solos argilo-arenosos e pedregosos, e.g., Chamaecrista absus (L.) H.S. Irwin \& Barneby, C. duckeana (P. Bezerra \& Afr. Fern.) H.S. Irwin $\&$ Barneby, C. rotundifolia (Pers.) Greene, $C$. supplex (Benth.) Britton \& Rose ex Britton \& Killip e Senna occidentalis (L.) Link.

\section{Tratamento taxonômico}

\section{Chave de identificação das espécies de Caesalpinioideae e Cercidoideae (Leguminosae) no Parque Estadual Mata da Pimenteira, Pernambuco, Brasil}

1. Folhas bipinadas.

2. Raque modificada em espinho; folíolos 4; ráquila achatada; foliólulos 32-129, lâmina foliar 1-4 $\times 1,2-2,5 \mathrm{~mm}$; legume moniliforme 5. Parkinsonia aculeata

2'. Raque não modificada em espinho; folíolos 5-13; ráquila cilíndrica; foliólulos 6-12, lâmina foliar $11-51 \times 6-31 \mathrm{~mm}$; legume não moniliforme......

3. Foliólulos todos opostos; legume bacoide 4. Libidibia ferrea

3'. Foliólulos todos alternos, ou raro, opostos apenas no folíolo terminal; legume típico.

2. Cenostigma pyramidale

1'. Folhas pinadas

4. Folhas 1-2-folioladas...

5. Arbusto a árvore 1,9-5 m alt.; folhas unifolioladas; pétalas brancas.

1. Bauhinia cheilantha

5'. Subarbusto ereto $80 \mathrm{~cm}$ alt.; folhas bifolioladas; pétalas amarelas.

3.4. Chamaecrista rotundifolia

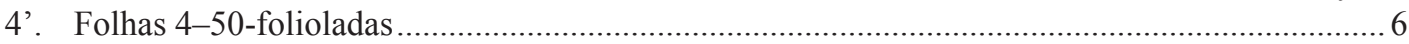

6. Nectário ausente no pecíolo e na raque......................................................................... 7

7. Ramos tomentosos; folhas paripinadas; folíolos opostos; flores assimétricas, pétalas com 13-29 × 14-19 mm, androceu heteromórfico, anteras poricidas; fruto legume bacóide 7.4. Senna spectabilis 
7'. Ramos glabros; folhas imparipinadas; folíolos alternos; flores actinomorfas, pétalas com 2-2,6× 0,6-1 mm, androceu homomórfico, anteras rimosas; fruto sâmara . 6. Pterogyne nitens

6'. Nectário presente no pecíolo e/ou na raque

8. Nectário presente no pecíolo e ausente na raque ...................................................................... 9

9. Folhas com folíolos lanceolados a elípticos; nectário peciolar globoso, côncavo; inflorescência racemosa...... 7.3. Senna occidentalis

9'. Folhas com folíolos oblongos ou oblanceolados, lineares; nectário peciolar estipitado, côncavo; flores isoladas ou fasciculares.

10. Subarbustos prostados; ramos vermelhos; estípulas cordadas

3.5. Chamaecrista supplex

10'. Subarbustos eretos; ramos verdes; estípulas lanceoladas a triangulares...... .. 11

11. Pétalas desiguais, a lateral com máculas vermelhas nas extremidades e as demais amarelas em toda sua extensão, estames 10 , heterodínamo.

3.2. Chamaecrista duckeana

11'. Pétalas equilongas, todas amarelas, estames 4 , isodínamos.

3.3. Chamaecrista pilosa var. luxurians

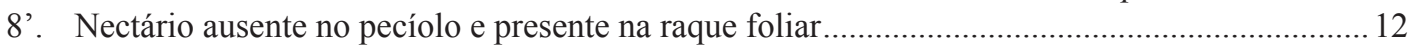

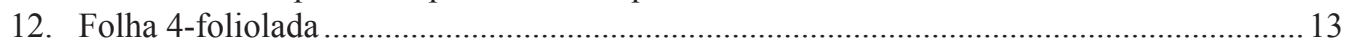

13. Erva ou subarbusto; fruto legume típico ................................... Chamaecrista absus

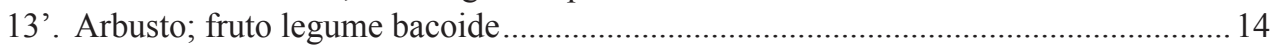

14. Ramos e folhas pubescentes a tomentosos; pétalas $6,5-7,5 \times 3,4 \mathrm{~mm}$, anteras heteromórficas; legume 7,5-13 cm compr.

..7.1. Senna macranthera

14'. Ramos e folhas glabros; pétalas 29-32 × 18-19 mm, anteras homomórficas; legume bacoide $21,3-30,9 \mathrm{~cm}$ compr. 7.5. Senna splendida

12'. Folha 6-8-foliolada 15

15. Ramos tomentosos; nectários no eixo principal da inflorescência digitiformes; anteras homomórficas; valvas elevadas na região da semente 7.6. Senna uniflora

15'. Ramos glabros; nectário ausente na inflorescência; anteras heteromórficas; valvas planocompressas 7.2. Senna obtusifolia

1. Bauhinia cheilantha (Bong.) Steud., Nomencl. Bot. (ed. 2) 1: 191.1840. Figs. 1a; 2a-c

Arbustos a árvores 1,9-5 m alt.; ramos cilíndricos, marrons, tomentosos, indumento esbranquiçado, lenticelas circulares a elípticas, cremes, esparsadas. Estípulas ca. 1,5 × $2 \mathrm{~mm}$, triangulares, tomentosas, persistentes; pecíolo canaliculado, 1-2,1 cm compr., tomentoso, nectário ausente. Folhas unifolioladas, unidas $1 / 2$ a $1 / 3$ do comprimento; lâmina foliar 27-82 × 21-75 $\mathrm{mm}$, base cordada, ápice arrredondado, margem ciliada, face abaxial pubescente, adaxial tomentosa, nervuras primárias e secundárias com mesmo calibre, proeminentes na face abaxial e impressas na adaxial, nectário ausente. Racemo com 2 flores por nó, terminal, 3,2-15,1 cm compr., nectário ausente; pedúnculo 2,5-5,2 cm compr., tomentuloso, sem bráctea; bractéola 3-5 $\times 0,8-1,2 \mathrm{~mm}$, triangular, tomentosa, uma ou duas, na base ou região mediana do pedicelo, persistente; sépalas ca. $25 \times 8 \mathrm{~mm}$, discretamente desiguais, triangulares, tomentulosas, verdes; pétalas 20,2-24 × 8-9 mm, equilongas, pubescentes, brancas, oblanceoladas, hipanto 7-10 mm compr.; filete $8-15 \mathrm{~mm}$ compr., estames 10 , levemente heterodínamos, anteras 8-11 mm compr., homomórficas, dorsifixas, oblongas, achatadas, rimosas, sem estaminódios; ovário 9-13 mm compr., seríceo ou setoso, oblongo. Legume típico, 3-10,5 $\times 0,4-1,3 \mathrm{~cm}$, linear, plano-compresso, pubescente, marrom. Sementes 6-7,2 × 4-5 mm, obovais, marrons.

Material examinado: Serra Talhada, Estação Experimental do IPA, 26.II.2010, fr., T.G.C. Menezes 11 (HESBRA); 4.IV.2010, fr., T.G.C. Menezes et al. 66 (HESBRA); PEMP, Campus da UAST, 2010, fr., M.E.O. Barbosa et al. 2 (HESBRA); PEMP, próximo ao Açudezinho, 29.III.2012, fl. e fr., T.R.G. Mariano et al. 1 (HESBRA); 9.VI.2016, fr., R.M.C. Leite et al. 1 (HESBRA); Serra Branca, 30.III.2009, fl., S.C.C. Júnior et al. 5 (HESBRA); 24.V.2011, fr., H.F.S. Carvalho et al. 10 (HESBRA).

Ocorre no Brasil, Bolívia e Paraguai (Vaz \& Tozzi 2003). No Brasil, ocorre em todos estados do Nordeste e nas regiões do Centro-Oeste 

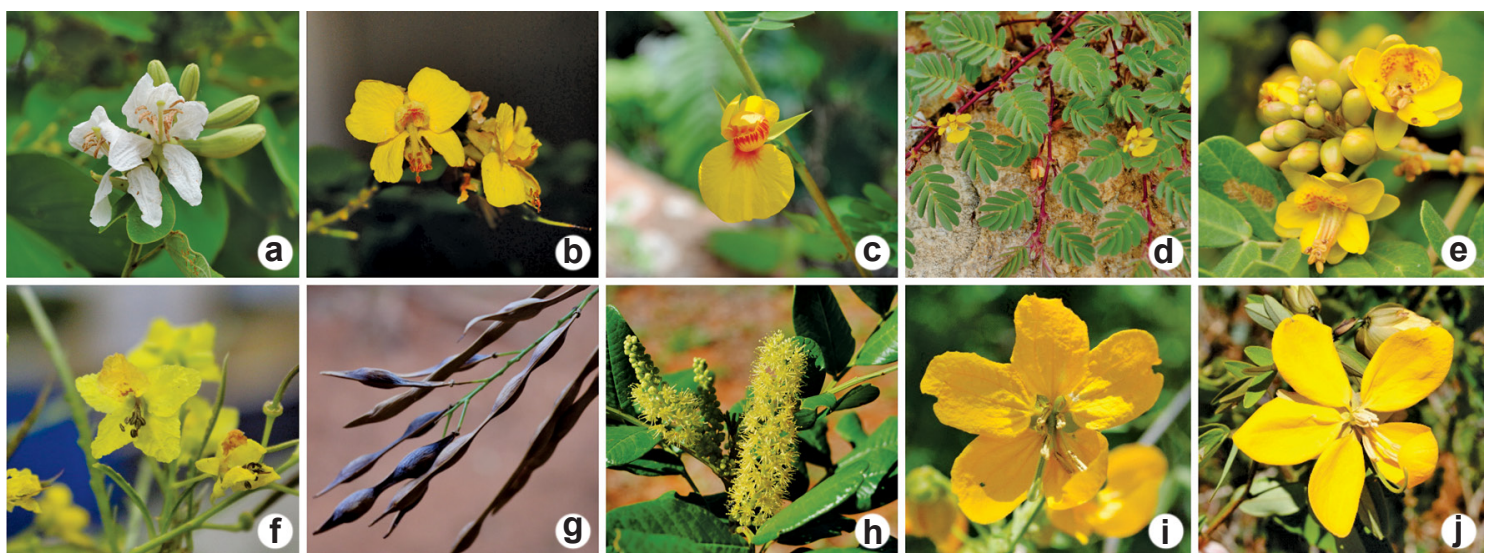

Figura 1 - a-j. Espécies de Caesalpinioideae (Leguminosae) do Parque Estadual Mata da Pimenteira (PE) - a. Bauhinia cheilantha; b. Cenostigma pyramidale; c. Chamaecrista duckeana; d. Chamaecrista supplex; e. Libidibia ferrea; f,g. Parkinsonia aculeata; h. Pterogyne nitens; i. Senna macranthera; j. Senna splendida. Fotos: a, b, c, d, e, h, i, j. A. Laurênio; f, g. Samara Matos.

Figure 1 - a-j. Species of Caesalpinioideae (Leguminosae) from Parque Estadual Mata da Pimenteira (PE) - a. Bauhinia cheilantha; b. Cenostigma pyramidale; c. Chamaecrista duckeana; d. Chamaecrista supplex; e. Libidibia ferrea; f,g. Parkinsonia aculeata; h. Pterogyne nitens; i. Senna macranthera; j. Senna splendida. Fotos: a, b, c, d, e, h, i, j. A. Laurênio; f, g. Samara Matos.

(Mato Grosso do Sul, Mato Grosso) e Sudeste (Minas Gerais, São Paulo), presente nos domínios fitogeográficos da Caatinga e Cerrado (BFG 2018). $\mathrm{Na}$ área de estudo, apresenta ampla distribuição e forma grandes populações, tanto em áreas preservadas, quanto em ambientes regenerantes, em solos argilo-arenosos e pedregosos. Em estudo fitossociológico desenvolvido em área do PEMP aparece como uma das espécies mais abundantes (Farias et al. 2016).

Bauhinia cheilantha é facilmente identificada pelas folhas bilobadas unidas $1 / 2$ a $1 / 3$ do comprimento e pelas pétalas brancas $(20,2-24 \times$ 8-9 mm). É bastante utilizada na região semiárida como forrageira, para produção de estaca e para recuperação florestal (Campanha \& Araújo 2010).

Floresce e frutifica de fevereiro a junho.

Nome popular: Pata-de-vaca ou mororó.

2. Cenostigma pyramidale (Tul.) Gagnon \& G.P. Lewis, PhytoKeys 71: 93. 2016. Figs. 1b; 2d-f

Árvores 3-12 m alt.; ramos cilíndricos, castanhos a acinzentados, glabros, às vezes, velutinos no ápice, indumento creme, lenticelas circulares a elípticas, cremes, adensadas. Estípulas ca. 0,6 $\times$ $0,3 \mathrm{~mm}$, triangulares, tomentosas, caducas; pecíolo cilíndrico, 1,3-4,2 cm compr., glabro, nectário ausente. Folhas bipinadas, folíolos 5, livres; lâmina foliar 11-51 × 7,5-31 mm, oboval, base oblíqua, ápice emarginado, margem ciliada, face abaxial pubescente, adaxial glabra, nervura primária cêntrica, secundárias de menor calibre, proeminentes na face abaxial e impressas na face adaxial, raque 1,9-3,8 cm compr., não modificada em espinho, tomentosa, cilíndrica a levemente canaliculada, nectário ausente, ráquila $2,3-7,5 \mathrm{~cm}$ compr., cilíndrica, foliólulos 6-10, alternos, ou raro, opostos apenas no folíolo terminal. Panícula terminal, 5,1$8,5 \mathrm{~cm}$ compr., nectário ausente; pedúnculo 2-2,6 $\mathrm{cm}$ compr., puberulento a pubescente, sem bráctea; bractéola ca. 1,2 $\times 0,2 \mathrm{~mm}$, lanceolada, tomentosa, uma, na base do pedicelo, caduca; sépalas 7,5-8,2 $\times 4-5,5 \mathrm{~mm}$, discretamente desiguais, lanceoladas, tomentulosas, verde-amarronzadas; pétalas 9-14 $\times$ $7,5-12,5 \mathrm{~mm}$, desiguais, suborbiculares a obovais, amarelas, adaxial com máculas vermelhas, hipanto 2-4 mm compr.; filete 1,2-7 mm compr., estames 10 , levemente heterodínamos, anteras $1,5-1,9 \mathrm{~mm}$ compr., homomórficas, não rostradas, dorsifixas, elípticas, achatadas, rimosas, sem estaminódios; ovário 3-3,5 mm compr., pubescente, elíptico. Legume $6,8-8,5 \times 1,5-2 \mathrm{~cm}$, pubérulo, verde a marrom, oblongo, plano-compresso. Sementes imaturas.

Material examinado: Serra Talhada, Estação Experimental do IPA - Lauro Bezerra, 26.II.2010, fl., S.G.C. Farias 9 (HESBRA); 22.III.2010, fr., T.G.C. Menezes et al. 43 (HESBRA); PEMP, III.2010, fl., T.G.C. Menezes 111 (HESBRA); 20.III.2011, fl., L. RodriguesLima 56 (HESBRA); 29.III.2012, fl. e fr., M.R.L. Oliveira et al. 1 (HESBRA); 29.III.2012, fr., A.T. Diniz et al. 1 (HESBRA). 


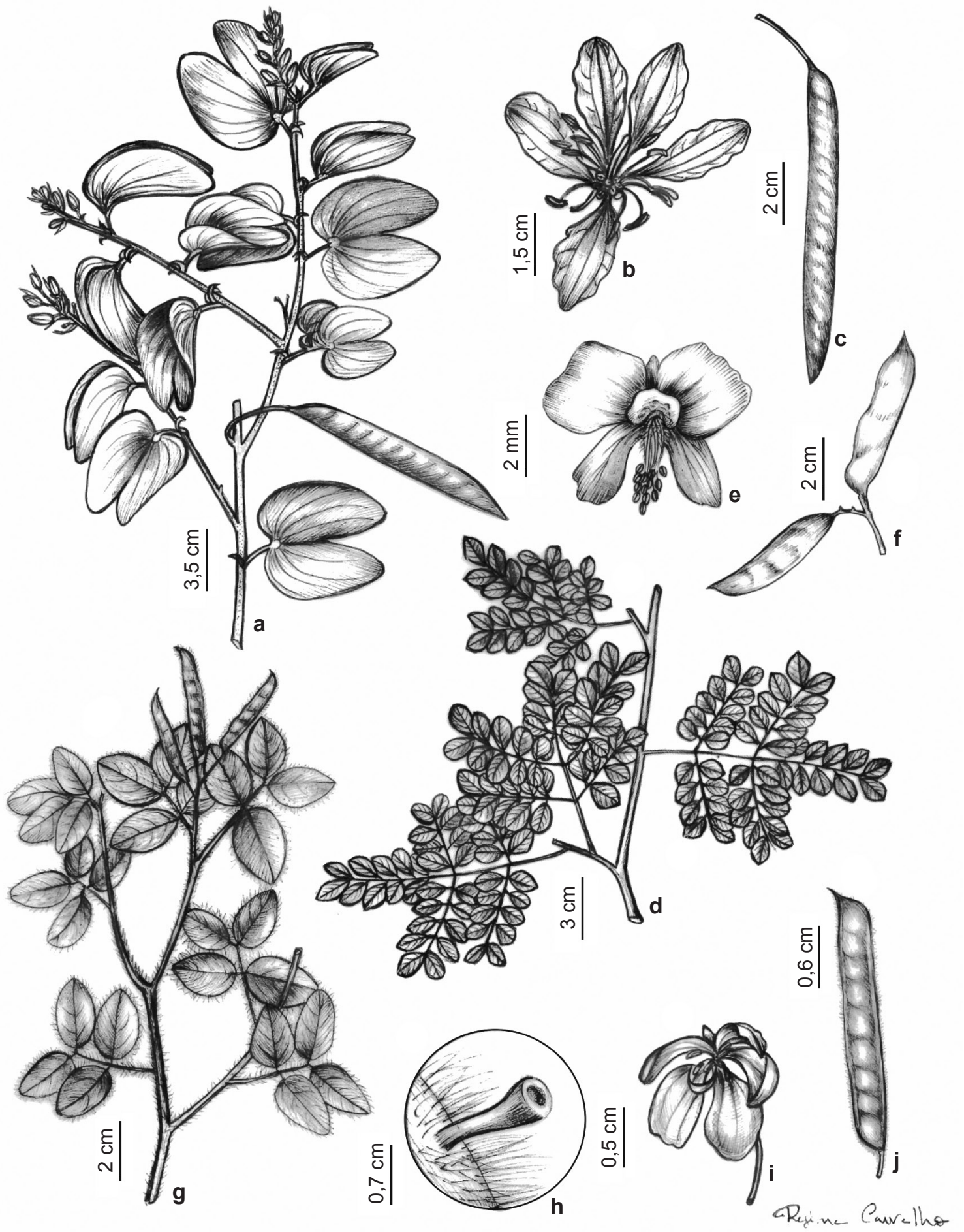

Figura 2 - a-c. Bauhinia cheilantha - a. ramo; b. flor; c. fruto. d-f. Cenostigma pyramidale - d. ramo; e. flor; f. fruto. g-j. Chamaecrista absus - g. ramo; h. detalhe do nectário extrafloral e do indumento; i. flor; j. fruto. (a-c. T.R.G. Mariano et al. 1; d-f. M.R.L. Oliveira et al. 1; g-j. A. Laurênio et al. 3356).

Figure 2 - a-c. Bauhinia cheilantha - a. branch; b. flower; c. fruit. d-f. Cenostigma pyramidale - d. branch; e. flower; f. fruit. g-j. Chamaecrista absus - g. branch; h. detail of the extrafloral nectary and the indumentum; i. flower; j. fruit. (a-c. T.R.G. Mariano et al. 1; d-f. M.R.L. Oliveira et al. 1; g-j. A. Laurênio et al. 3356). 
Espécie endêmica do Brasil, ocorrendo nas regiões Norte (Amazonas) e Nordeste (Alagoas, Bahia, Ceará, Maranhão, Paraíba, Pernambuco, Piauí, Sergipe), nos domínios fitogeográficos Amazônico e Caatinga (BFG 2018). Espécie frequente no PEMP, especialmente em áreas planas, tanto em áreas com vegetação preservada quanto em regeneração, sobretudo em solos argiloarenosos e pedregosos. No estudo fitossociológico de Farias et al. (2016) está entre as cinco espécies mais abundantes do componente lenhoso do PEMP.

Espécie morfologicamente relacionada à Libidibia ferrea, com a qual compartilha o hábito arbóreo, folhas bipinadas, flores amarelas com pétala adaxial com máculas vermelhas. Diferencia-se, principalmente, por apresentar foliólulos alternos, raramente opostos no folíolo terminal e fruto legume.

Cenostigma Tul. foi reunido a Poincianella Britton \& Rose, gênero segregado de Caesalpinia L., formando assim o conceito amplo do gênero (Gagnon et al. 2016).

Floresce e frutifica nos meses de fevereiro e março.

Nome popular: catingueira.

\section{Chamaecrista Moench.}

Gênero com cerca de 330 espécies, distribuição tropical e subtropical, maior número de espécies na região Neotropical (266 spp.) e centro de diversidade na América do Sul (Lewis 2005). Para o Brasil, são registradas 256 espécies presentes em todas as regiões e nos domínios fitogeográficos Amazônico, Caatinga, Cerrado, Atlântico, Pampa e Pantanal (BFG 2018). Neste estudo foram encontradas cinco espécies.

Chamaecrista pode ser reconhecido pelas folhas usualmente sem nectários, flores amarelas, fortemente assimétricas e com um par de bractéolas desde o meio do pedicelo até o ápice deste, androceu actinomorfo e frutos elasticamente deiscentes (Irwin \& Barneby 1982).

3.1. Chamaecrista absus (L.) H.S. Irwin \& Barneby, Mem. New York Bot. Gard. 35: 664. 1982.

Fig. $2 g-j$

Ervas ou subarbustos eretos ca. $0,4 \mathrm{~m}$ alt.; ramos cilíndricos, verdes, levemente estriados, pubescentes, indumento creme, sem lenticelas. Estípulas 2-4×0,8-1 mm, triangulares, tomentosas, persistentes; pecíolo canaliculado, 1,7-4 cm compr., piloso, nectário ausente. Folhas paripinadas, folíolos 4, livres; lâmina foliar 5-27 $\times 15-19 \mathrm{~mm}$, oboval, base oblíqua a obtusa, ápice obtuso a arrredondado mucronulado, margem ciliada, face abaxial pubescente, adaxial pubescente, nervura primária cêntrica a subcêntrica, secundárias de menor calibre, proeminentes na face abaxial, obscuras na face adaxial, raque 0,4-0,8 cm compr., não transformada em espinho, pubescente, canaliculada, nectário 1 , entre cada par de folíolos, ligulado. Racemo terminal, 1,3-5,2 $\mathrm{cm}$ compr., nectário ausente; pedúnculo $0,7-1 \mathrm{~cm}$ compr., ciliado, setoso; bráctea 3-3,5 × 0,5-0,8, triangular, ciliada, setosa; bráctéola 2-2,3 × 1,3-2,5 $\mathrm{mm}$, triangular ciliada, setosa, duas, na região mediana do pedicelo, persistente; sépalas 4-5× 2-3 mm, discretamente desiguais, lanceoladas a lanceoladas, setosas, verdes; pétalas 5,1-5,4 $\times$ 2,1-2,8 mm, equilongas, glabras, espatuladas, hipanto ausente; filete 1,9-2 $\mathrm{mm}$ compr., estames 2-4, heterodínamos, anteras 2-2,5 mm compr., homomórficas, não rostradas, basifixas, oblongas, achatadas, poricidas, sem estaminódios; ovário ca. 2,5 mm compr., seríceo, densamente setoso nas suturas, oblongo. Legume 2,7-4 × 0,4-0,7 cm, estreitamente oblongo a linear, plano-compresso, setoso. Sementes ca. $6 \times 3-3,1 \mathrm{~mm}$, obovais, verdes, plano-compressas.

Material examinado: Serra Talhada, PEMP, próximo a Serra Branca, 5.V.2014, fl e fr., A. Laurênio et al. 3356 (HESBRA).

Espécie distribuída nas Américas (Irwin \& Barneby 1982). Em território brasileiro pode ser encontrada nas regiões Nordeste (Alagoas, Bahia, Ceará, Paraíba, Pernambuco, Piauí, Rio Grande do Norte, Sergipe) e no Centro-Oeste (Goiás), nos domínios Caatinga e Cerrado, em áreas antropizadas, em Caatinga stricto sensu, Floresta estacional semidecidual e Restinga (BFG 2018). É uma espécie raramente observada no PEMP, ocorrendo em áreas planas (400-500 m alt.) e abertas.

Chamaecrista absus se diferencia das demais espécies do gênero ocorrentes no PEMP por ser a única a apresentar dois pares de folíolos por folha, nectário ligulado na raque, frutos revestidos por tricomas setosos no pedúnculo e no ovário.

Floresce em maio.

3.2. Chamaecrista duckeana (P. Bezerra \& Afr. Fern.) H.S. Irwin \& Barneby, Mem. New York Bot. Gard. 35: 861. 1982. Figs. 1c; 3a-d

Subarbustos eretos $0,6-0,7 \mathrm{~m}$ alt.; ramos cilíndricos, verde-claros, levemente estriados, 


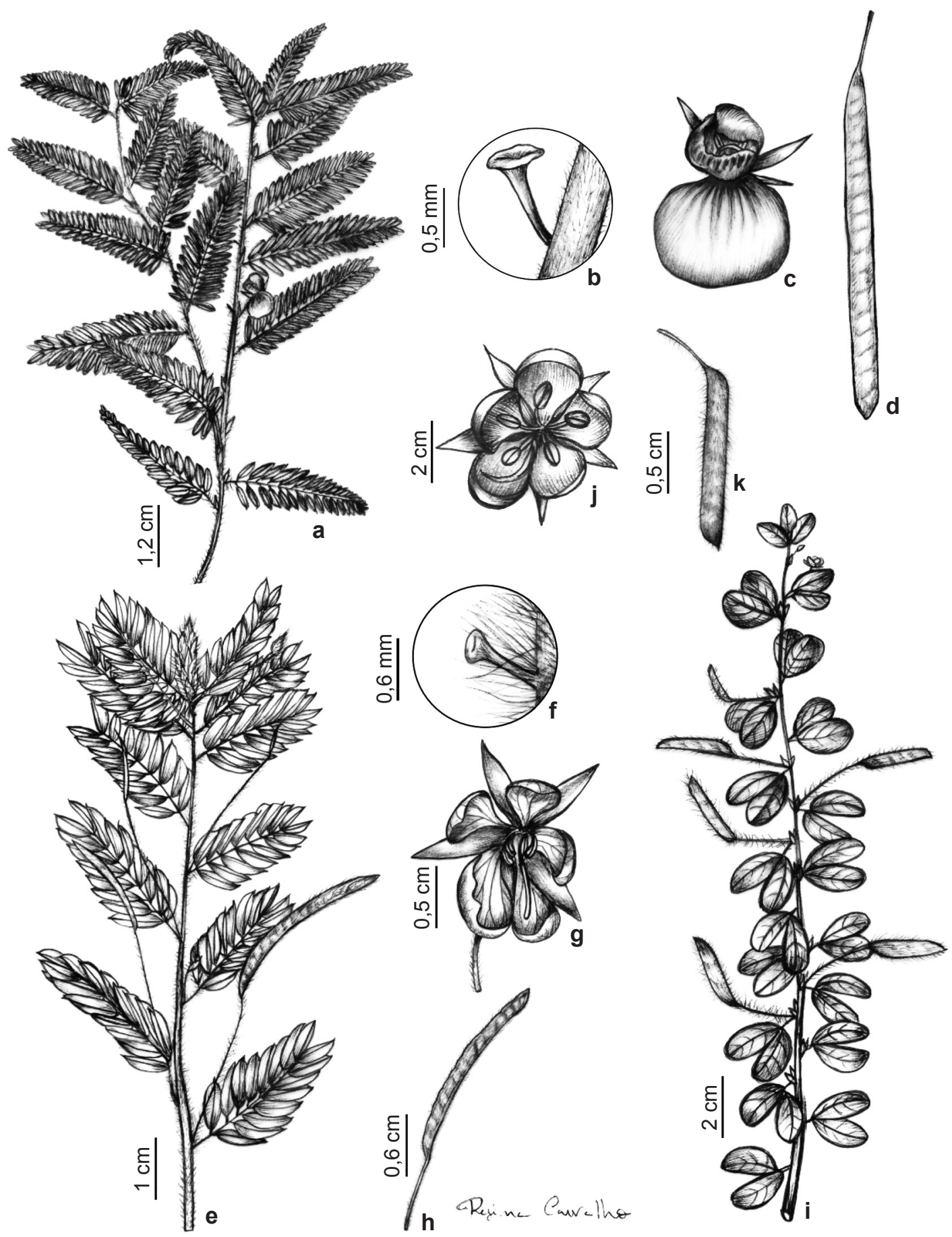

Figura 3 - a-d. Chamaecrista duckeana - a. ramo; b. detalhe do nectário extrafloral e do indumento; c. flor; d. fruto. e-h. Chamaecrista pilosa var. luxurians - e. ramo; f. detalhe do nectário extrafloral e do indumento; g. flor; h. fruto. i-k. Chamaecrista rotundifolia - i. ramo; j. flor; k. fruto. (a-d. S.S. Matos et al. 526; e-h. S.S. Matos et al. 511; i-k. S.S. Matos et al. 510).

Figure 3 - a-d. Chamaecrista duckeana - a. branch; b. detail of the extrafloral nectary and the indumentum; c. flower; d. fruit. e-h. Chamaecrista pilosa var. luxurians - e. branch; f. detail of the extrafloral nectary and the indumentum; g. flower; h. fruit. i-k. Chamaecrista rotundifolia - i. branch; j. flower; k. fruit. (a-d. S.S. Matos et al. 526; e-h. S.S. Matos et al. 511; i-k. S.S. Matos et al. 510). 
vilosos, indumento creme, sem lenticelas. Estípulas 5-20 × 1-2 mm, triangulares a estreitamente lanceoladas, glabras a pubérulas, persistentes; pecíolo canaliculado, 0,4-0,7 cm compr., piloso, nectário 1, na região mediana do pecíolo, calicioide. Folhas paripinadas, folíolos 15-50, livres; lâmina foliar 18-25 × 2-25 mm, estreitamente oblonga a linear, base oblíqua, ápice agudo apiculado, margem ciliada, face abaxial e adaxial glabras, nervura primária excêntrica, secundárias de menor calibre, proeminentes na face abaxial, discretas na face adaxial, raque 2,5-12 cm compr, não transformada em espinho, viloso, canaliculada, nectário ausente. Flores isoladas, supra axilares, nectário ausente, sem bráctea; bractéola 4-6× 0,4-0,6 mm, triangular, pubescente, duas, acima da região mediana do pedicelo, persistente; sépalas 9,5-13 × 0,5-3 $\mathrm{mm}$, discretamente desiguais, lanceoladas a lanceovadas, pubescentes, verdeamareladas; pétalas 5-6 × 2,5-2,8 mm, desiguais, glabras, a lateral maior, subreniforme com máculas vermelhas nas extremidades, obovais, hipanto ausente, filete $0,5-1 \mathrm{~mm}$ compr.; estames 10 , heterodínamos, 2 maiores e 8 menores, anteras 3-9,5 mm compr., homomórficas, não rostradas, basifixas, oblongas, achatadas, poricidas, sem estaminódios; ovário ca. 0,4 mm compr., seríceo, densamente setoso, oblongo. Fruto não observado. Material examinado: Serra Talhada, PEMP, Lagoa Pimenteira III, 15.IV.2014, fl. e fr., S.S. Matos et al. 526 (HESBRA).

Material adicional: Santa Cruz da Baixa Verde, Olho d'Água, Serra da Madeira, 8.VIII.2013, fl., J.M. Bento 4 (HESBRA).

Espécie endêmica do Nordeste do Brasil, encontrada nos estados de Alagoas, Bahia, Ceará, Paraíba, Pernambuco, Piauí, Rio Grande do Norte e Sergipe, ocorrendo em áreas antropizadas e em Caatinga stricto sensu (BFG 2018). No PEMP, ocorre de forma ocasional em áreas planas sobre solos argilo-arenosos, às vezes, relacionada aos corpos d'água, não forma grandes populações.

Entre as espécies ocorrentes no PEMP, $C$. duckeana assemelha-se a $C$. pilosa com a qual compartilha o hábito herbáceo, nectário calicioide localizado na região mediana do pecíolo e flores isoladas. Entretanto, estas espécies distinguem-se principalmente pelo número de folíolos 15-25 pares (vs. 4-8 pares em C. pilosa) e pétalas amarelas desiguais em que a lateral é maior e subreniforme com máculas vermelhas nas extremidades ( $v s$. pétalas amarelas equilongas) em $C$. duckeana.

Floresce e frutifica em abril.
3.3. Chamaecrista pilosa var. luxurians (Benth.) H.S. Irwin \& Barneby, Mem. New York Bot. Gard. 35: 720. 1982.

Fig. 3e-h

Subarbustos eretos $0,8-0,9 \mathrm{~m}$ alt.; ramos cilíndricos, verde-claros, vilosos, indumento creme, sem lenticelas. Estípulas 6-11,5 × 1,4-3 $\mathrm{mm}$, lanceoladas, pilosas, persistentes; pecíolo canaliculado, 0,3-0,5 cm compr., piloso, nectário 1 , na região mediana do pecíolo, calicioide. Folhas paripinadas, folíolos 8-18, livres; lâmina foliar 5-15 × 1-4 mm, oblanceolada, base oblíqua, ápice arrredondado apiculado, margem inteira a ciliada, glabra em ambas as faces, nervura primária excêntrica, secundárias de menor calibre, proeminentes na face abaxial, evidentes na face adaxial, raque 3-3,7 cm compr., não transformada em espinho, viloso, canaliculada, nectário ausente. Flores isoladas, supra axilares, nectário ausente, sem bráctea; bractéola 2,5-3,8 × 0,3-0,5 mm, triangular, setosa, duas, acima da região mediana do pedicelo, persistente; sépalas 6-6,5 × 1,2-2 mm, discretamente desiguais, lanceoladas, hirsutas, verdes; pétalas 5-5,5 × 2,5-4,5 mm, equilongas, glabras, obovais, hipanto ausente; filete $1-1,2 \mathrm{~mm}$ compr., estames 4, isodínamos, anteras ca. 4,5 mm compr., homomórficas, não rostradas, basifixas, oblongas, achatadas, poricidas, sem estaminódios; ovário 5-5,2 mm compr., seríceo, densamente setoso, oblongo. Legume 2,5-4,5 × 0,4-0,5 cm, linear, plano-compresso, seríceo, verde. Sementes 2,8-3 × 2-3,1 mm, obovais, castanho-claras, plano-compressas.

Material examinado: Serra Talhada, PEMP, Lagoa pimenteira III, 15.IV.2014, fl. e fr., S.S. Matos et al. 511 (HESBRA).

Material adicional: Calumbi, Rio Pajeú, Margem do Rio Pajeú, 17.XII.2011, fl. e fr., W. Cordeiro et al. 139 (HESBRA); 4.V.2012, fl. e fr., W. Cordeiro et al. 260 (HESBRA).

Espécie endêmica do Brasil, ocorrendo nas regiões Norte (Tocantins), Nordeste (Bahia, Ceará, Maranhão, Pernambuco, Rio Grande do Norte), Centro-Oeste (Goiás) e Sudeste (Minas Gerais), nos domínios fitogeográficos Caatinga, Cerrado e Atlântico; presente em áreas antropizadas, em Caatinga stricto sensu e Campo rupestre (Chamaecrista in Flora do Brasil 2020 em construção). Tem ampla distribuição no PEMP, tanto em áreas planas, quanto no topo da Serra Talhada, em solos arenosos, argilosos ou pedregosos, em ambientes perturbados e melhor preservados, e também em torno de corpos d'água.

É reconhecida pelo número de folíolos que varia de 4 a 8 pares por folhas e as pétalas 
amarelas equilongas. A distinção entre C. pilosa e C. duckeana foi discutida nos comentários desta última espécie.

Floresce e frutifica em abril.

Nome popular: mundubim.

3.4. Chamaecrista rotundifolia (Pers.) Greene, Pittonia 4(20D): 31. 1899.

Fig. 3i-k

Subarbustos eretos ca. $0,8 \mathrm{~m}$ alt.; ramos cilíndricos, verde-claros, vilosos, indumento creme, sem lenticelas. Estípulas 5-10 × 2,5-4 $\mathrm{mm}$, cordadas, pilosas, persistentes; pecíolo canaliculado, 0,3-0,7 cm compr., piloso, nectário ausente. Folhas paripinadas, folíolos 2, livres; lâmina foliar 4-31 ×4-17 mm, oboval, base oblíqua, ápice arrredondado mucronado, margem ciliada, face abaxial pubescente a glabra, adaxial glabra, nervura primária excêntrica, 1-2 secundárias com quase mesmo calibre, proeminentes em ambas as faces; raque muito reduzida, nectário ausente. Flores isoladas, axilares, nectário ausente, sem bráctea; bractéola $2-3 \times 0,3-0,4$ $\mathrm{mm}$, triangular, setosa, duas, acima da região mediana do pedicelo, persistente; sépalas 5-6,2 $\times$ $1,2-1,5 \mathrm{~mm}$, discretamente desiguais, lanceoladas, hirsutas, margem ciliada, verdes; pétalas 4-6× 1,8-4 mm, equilongas, glabras, obovais, hipanto ausente, filete $0,5-0,8 \mathrm{~mm}$ compr., estames 4-5, heterodínamos, anteras 1,2-4 mm compr., homomórficas, não rostradas, basifixas, oblongas, achatadas, poricidas, sem estaminódios, ovário 3,2 mm compr., seríceo, densamente setoso nas suturas, oblongo. Legume $1,9-3 \times 0,3-0,4 \mathrm{~cm}$, linear, plano-compresso, pubescente, marrom. Sementes 2,9-3,1 × 2-2,2 mm, obovais, castanhoclaras, plano-compressas.

Material examinado: Serra Talhada, PEMP, Lagoa Pimenteira III, 15.IV.2014, fl. e fr., S.S. Matos et al. 510 (HESBRA).

Material adicional: Santa Cruz da Baixa Verde, Olho d'Água, Serra da Madeira, 8.VIII.2013, fr., A. Laurênio et al. 3269 (HESBRA). Triunfo, Pico do Papagaio, 18.V.2015, fl. e fr., A. Laurênio et al. 3747 (HESBRA).

Espécie com distribuição Neotropical, ocorrendo desde os Estados Unidos até a Argentina (Irwin \& Barneby 1982). No Brasil, é encontrada nas regiões Norte (Rondônia, Tocantins), Sul (Paraná, Rio Grande do Sul) e em todos os estados do Nordeste, Centro-Oeste e Sudeste, nos domínios Amazônico, Caatinga, Cerrado, Atlântico, Pampa, Pantanal (BFG 2018). No PEMP foi raramente observada, em áreas abertas e margem de estradas, em solos argilo-arenosos.
Chamaecrista rotundifolia é facilmente diferenciada entre as espécies do mesmo gênero do PEMP por ser uma erva com folhas bifolioladas.

Floresce e frutifica em abril.

3.5. Chamaecrista supplex (Benth.) Britton \& Rose ex Britton \& Killip, Ann. New York Acad. Sci. 35(3): 185. 1936.

Figs. 1d; 4a-d

Subarbustos prostados; ramos cilíndricos, vermelhos, glabros a pubecentes, indumento creme, sem lenticelas. Estípulas 2,5-4 × 1,5-2 $\mathrm{mm}$, cordadas, hirsutas, persistentes; pecíolo canaliculado, 0,4-0,5 cm compr., glabro a pubescente, nectário 1 , na região mediana do pecíolo, calicioide; folhas paripinadas, folíolos 6-10, livres, lâmina foliar 3-7,5 × 1-2 mm, estreitamente oblonga, base oblíqua, ápice arredondado mucronado, margem ciliada, face abaxial piloso, adaxial glabra, nervura primária excêntrica, 1-3 secundárias com quase mesmo calibre, proeminentes em ambas as faces, raque 0,4 $1 \mathrm{~cm}$ compr., não transformada em espinho, viloso, canaliculada, nectário ausente. Flores isoladas, axilar, nectário ausente; sem bráctea; bractéola $1,5-2 \times 0,4-0,5 \mathrm{~mm}$, triangular, pubescente, duas, acima da região mediana do pedicelo, persistente; sépalas 3-3,5 × 0,8-1 mm, discretamente desiguais, lanceoladas, hirtas, margem ciliada, verdes; pétalas $2,6-3,7 \times 1,4-2 \mathrm{~mm}$, desiguais, glabras, lateral maior falcada, espatuladas, hipanto ausente, filete 0,7-1 mm compr., estames 4 , heterodínamos, 2 maiores e 2 menores, anteras $0,8-1,7 \mathrm{~mm}$ compr., homomórficas, não rostradas, basifixas, oblongas, achatadas, poricidas, sem estaminódios, ovário 1,9-3,2 mm compr., seríceo, densamente setoso, oblongo. Legume $0,9-1,2 \times 0,2-0,3 \mathrm{~cm}$, oblongo, plano-compresso, piloso, verde a verde-vináceo. Sementes 2,6 $62,8 \mathrm{~mm}$, ovais, plano-compressas, verdes.

Material examinado: Serra Talhada, PEMP, Lagoa Pimenteira III, 15.IV.2014, fl. e fr., S.S. Matos et al. 514 (HESBRA).

Material adicional: Petrolina, 9.III.1979, fl., D. Andrade-Lima 9482 (IPA). Santa Maria da Boa Vista, Fazenda Milano, 28.VII.1984, fl., P. Pinto et al. (IPA41779).

No Brasil, ocorre no Norte (Pará, Tocantins), Nordeste (Bahia, Ceará, Maranhão, Paraíba, Pernambuco, Piauí, Rio Grande do Norte), CentroOeste (Distrito Federal, Goiás, Mato Grosso) e Sudeste (Minas Gerais, Rio de Janeiro), nos domínios fitogeográficos Amazônico, Caatinga stricto sensu, Cerrado lato sensu e Atlântico, 


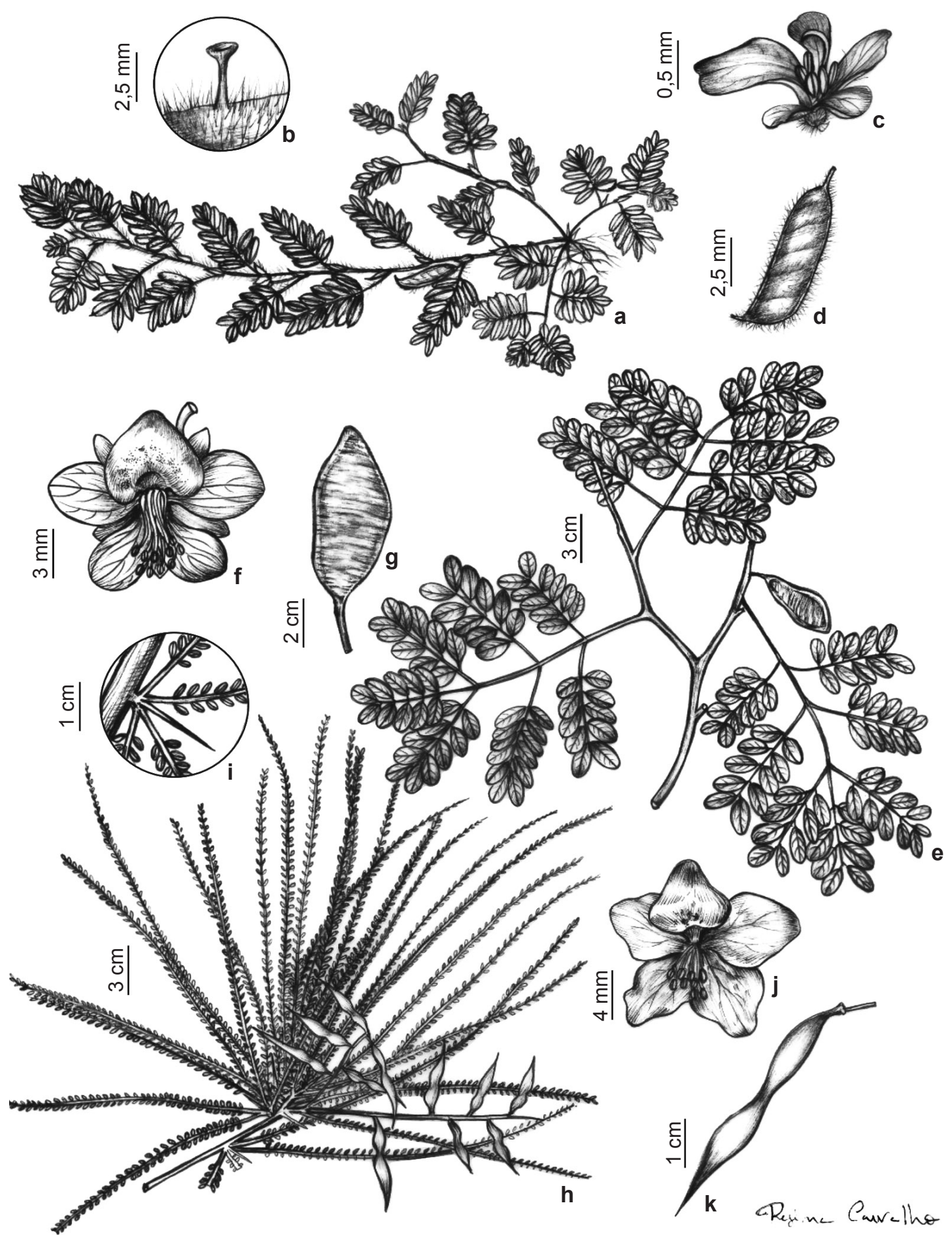

Figura 4 - a-d. Chamaecrista supplex - a. hábito; b. detalhe do nectário extrafloral e do indumento; c. flor; d. fruto. e-g. Libidibia ferrea - e. ramo; f. flor; g. fruto. h-k. Parkinsonia aculeata - h. ramo; i. detalhe da folha bipinada com raque modificada em espinho; j. flor; k. fruto. (a-d. S.S. Matos et al. 514; e-g. L.K.A. Lima et al. 5; h-k. W. Cordeiro et al. 375).

Figure 4 - a-d. Chamaecrista supplex - a. habit; b. detail of the extrafloral nectary and the indumentum; c. flower; d. fruit. e-g. Libidibia ferrea - e. branch; f. flower; g. fruit. h-k. Parkinsonia aculeata - h. branch; i. detail of biped leaf with modified rake in thorn; j. flower; k. fruit. (a-d. S.S. Matos et al. 514; e-g. L.K.A. Lima et al. 5; h-k. W. Cordeiro et al. 375). 
em áreas antrópicas, (BFG 2018). No PEMP, é raramente encontrada e está relacionada a afloramentos rochosos ou solo com pedregulhos em margem de lagoa.

Chamaecrista supplex pode ser facilmente identificada pelo conjunto de caracteres, hábito prostrado, lâmina foliar reduzida $(3-7,5 \times 1-2$ $\mathrm{mm})$, estípulas cordadas $(2,5-4 \times 1,5-2 \mathrm{~mm}) \mathrm{e}$ pétalas desiguais.

Floresce e frutifica em março.

4. Libidibia ferrea (Mart.) L.P. Queiroz, Legum. Caatinga 130: 2009.

Figs. 1e; 4e-g

Árvores 3-8 m alt.; ramos cilíndricos, marrons, tomentosos, indumento creme, lenticelas circulares a elípticas, cremes, adensadas. Estípulas $1-1,2 \times 0,7-0,8 \mathrm{~mm}$, triangulares a deltoide, tomentosas, caducas; pecíolo cilíndrico, 1,7-3,2 cm compr., tomentoso, nectário ausente. Folhas bipinadas, folíolos 5-13, opostos, livres; lâmina foliar 12,5-22 × 6-11 mm, oboval, base oblíqua, ápice emarginado, margem ciliada, face abaxial pubescente, adaxial puberulento, nervura primária cêntrica, secundárias de menor calibre, discretas na face abaxial e proeminentes na face adaxial, raque 2,2-7,5 cm compr., não modificada em espinho, glabra a pubescente, cilíndrica, nectário ausente, ráquila 2-7,2 cm compr., cilíndrica, foliólulos 10 12, sempre opostos. Panícula, terminal, 4,5-11,5 cm compr., nectário ausente, pedúnculo 0,6-3,7 cm compr., pubescente a puberulento; sem bráctea; bractéola ca. 1,3 ×0,5 mm, triangular, tomentosa, uma, na base do pedicelo, caduca; sépalas 6-7,5 $\times 3,5 \mathrm{~mm}$, discretamente desiguais, triangulares, glabras a pubescentes, verde-claras; pétalas 8,5-9 $\times$ 4-6 mm, desiguais, glabras, amarelas, adaxial rômbica com máculas vermelhas, obovais, hipanto 2-3 mm compr.; filete 12-20,5 mm compr., estames 10, heterodínamos, 5 externos maiores e 5 internos menores, anteras 1-1,2 mm compr., homomórficas, não rostradas, dorsifixas, elípticas, cilíndricas, rimosas, sem estaminódios; ovário $4 \mathrm{~mm}$ compr., pubescente, oblongo. Legume bacoide, 3,3-8,9 $\times$ 2-2,4 cm, oblongo, plano-compresso, pubérulo, marrom escuro. Sementes 8,5-9 × 7-8,5 mm, largamente elípticas, marrons.

Material examinado: Serra Talhada, PEMP, Estação Experimental do IPA - Lauro Bezerra, PEMP, 26.II.2010, fl., T.G.C. Menezes et al. 7 (HESBRA); subida para Serra Branca, 30.II.2009, fl. e fr., L.K.A. Lima et al. 5 (HESBRA); PEMP, IV.2010, fr., T.G.C. Menezes et al. 157 (HESBRA); Serra Branca, 6.I.2011, fl., R.S. Cordeiro et al. 191 (HESBRA).
Espécie distribuída nas florestas secas da região Neotropical (Queiroz 2009). No Brasil está presente em todos os estados da região Nordeste e no Sudeste (Espírito Santo, Minas Gerais, Rio de Janeiro), ocorrendo nos domínios fitogeográficos da Caatinga, Cerrado e Atlântico, nos tipos vegetacionais Caatinga stricto sensu, Carrasco, Floresta ciliar, Floresta estacional decidual, Floresta estacional semidecidual e Floresta ombrófila (BFG 2018). Embora não forme grande população, tem ampla distribuição na área de estudo pela presença de indivíduos isolados em diferentes áreas. Em estudo fitossociológico realizado no PEMP (Farias et al. 2016), foram registrados cerca de 18 ind./ha de L. ferrea.

Libidibia ferrea é diferenciada das demais espécies presentes no PEMP por apresentar hábito arbóreo, folhas bipinadas, folíolos opostos, pétalas amarelas obovais (adaxial rômbica com máculas vermelhas) e legume bacoide.

Floresce em janeiro e fevereiro e frutifica em abril.

Nome popular: pau-ferro ou jucá.

5. Parkinsonia aculeata L., Sp. Pl. 1: 375.1753.

Figs. 1f,g; 4h-k

Árvores 2-3 m alt.; ramos cilíndricos, verdes, glabros, sem lenticelas. Estípulas 1-2 $\times$ 0,2-0,4 mm, modificadas em espínhos cônicos, glabras, persistentes; pecíolo cilíndrico, 0,4-0,8 cm compr., pubescente a tomentoso, nectário ausente. Folhas bipinadas, folíolos 4, livres; lâmina foliar 1-4 × 1,2-2,5 mm, oboval a elíptica, base oblíqua, ápice retuso, margem ciliada, face abaxial pubérula, adaxial pubescente, nervura primária cêntrica, secundárias obscuras em ambas as faces, raque $0,7-1 \mathrm{~cm}$ compr., modificada em espinho, tomentosa, cilíndrica, nectário ausente, ráquila 3,5-34 cm compr., achatada, foliólulos 32-129, opostos ou alternos. Racemo terminal, 3,5-12,2 cm compr., nectário ausente; pedúnculo 0,6-2,5 cm compr., pubescente, sem bráctea; bractéola 1-1,3 $\times 0,4-0,7 \mathrm{~mm}$, triangular, tomentosa, uma, na base do pedicelo, caduca; sépalas 6,5-7 × 2-2,2 $\mathrm{mm}$, discretamente desiguais, triangulares, glabro a pubérulo, verdes; pétalas 6-8,5 × 5-6,5 mm, desiguais, glabras, pubérulas na base, amarelas, adaxial subreniforme com máculas vermelhas, truladas, hipanto 1,5-2 mm compr.; filete 6,5-7,5 mm compr.; estames 10, levemente heterodínamos, 5 externos maiores e 5 internos menores, anteras 1,8-2 mm compr., homomórficas, não rostradas, dorsifixas, elípticas, cilíndricas, rimosas, sem 
estaminódios; ovário 4,5-7 mm compr., seríceo, oblongo. Legume moniliforme, 4,6-10,5 × 0,6-0,8 $\mathrm{cm}$, glabro, marrom, linear. Sementes $8-9 \times 3,5-4$ $\mathrm{mm}$, elipsoides, marrons esverdeadas.

Material examinado: Serra Talhada, PEMP, Margem do Açude do Saco, 11.IX.2011, fl. e fr., W. Cordeiro et al. 375 (HESBRA).

Material adicional: Brejo da Madre de Deus, 31.X.1994, fl., Z. Travassos et al. 232 (PEUFR). Custódia, 11.VII.1990, fl., R. Pereira et al. 374 (IPA).

Amplamente distribuída na América e África tropicais (Queiroz 2009). Está presente no Nordeste (Alagoas, Bahia, Maranhão, Paraíba, Pernambuco, Piauí), Centro-Oeste (Mato Grosso do Sul), Sudeste (São Paulo) e Sul (Rio Grande do Sul) do Brasil, encontrada nos domínios fitogeográficos da Caatinga, Atlântico, Pampa, Pantanal e em áreas antropizadas, em vegetação de Caatinga stricto sensu, campo limpo, Cerrado lato sensu, Floresta ciliar, Floresta estacional semidecidual (Romão \& Mansano 2016). No PEMP, está associada aos corpos d'água, ocorrendo na margem de açudes e no interior de lagoas rasas.

Parkinsonia aculeata tem características bastante distintivas em relação aos táxons de Caesalpinioideae encontrados no PEMP, especialmente pelas folhas bipinadas com raque modificada em espinho e apenas quatro folíolos com ráquila achatada, foliólulos numerosos (32-129) e pequenos $(1-4 \times 1,2-2,5 \mathrm{~mm})$ e pelo legume moniliforme.

Floresce e frutifica em setembro.

Nome popular: turco.

6. Pterogyne nitens Tul., Ann. Sci. Nat., Bot., sér. 2 20: 140.1843.

Figs. 1h; 5a-c

Árvores 6-10 m alt.; ramos cilíndricos, castanhos, glabros, lenticelas circulares a elípticas, cremes, adensadas. Estípulas 0,4-0,5 × 0,3-0,4 $\mathrm{mm}$, triangulares, pubescentes, caducas; pecíolo cilíndrico a subcilíndrico, 1,3-2,3 cm compr., pubérulo, nectário ausente. Folhas imparipinadas, folíolos 8-10, alternos, glabros, livres; lâmina foliar 2,4-5,4 × 1-2,6 mm, elípticas a largamente elípticas, base obtusa a oblíqua, ápice emarginado, margem inteira, face abaxial pubérula, adaxial glabra, nervura primária cêntrica, secundárias de menor calibre, proeminentes na face abaxial e impressas na face adaxial, raque 5,3-8,6 cm compr., não modificada em espinho, glabra a pubescente, canaliculada, nectário ausente. Racemo axilar, 2,1-5,9 cm compr., nectário ausente; pedúnculo 0,3-0,5 cm compr., tomentoso, sem bráctea; bractéola 1-1,2 × 0,9-1 $\mathrm{mm}$, deltoide, tomentosa, uma, na base do pedicelo, persistente; flor actinomorfa; sépalas 1,5-2,3 $\times$ 0,7-1,2 mm, levemente desiguais, triangulares, pubescentes, verdes; pétalas 2-2,6 × 0,6-1 mm, equilongas, pubescentes, amarelas a cremes, oblanceoladas, hipanto ca. $1 \mathrm{~mm}$; filete 2,5-3 mm compr., estames 10 , isodínamos, anteras $0,3-0,5 \mathrm{~mm}$ compr., homomórficas, não rostradas, dorsifixas, elípticas, cilíndricas, rimosas, sem estaminódios; ovário 1,2 mm compr., seríceo, setoso, elíptico. Sâmara 1,6-4,4 ×0,5-1,5 cm, glabra, marrom claro; núcleo seminífero $0,8-1,8 \times 0,4-1,2 \mathrm{~cm}$, ovoide; ala $0,9-2,9 \times 0,5-1,5 \mathrm{~cm}$. Sementes $11-13 \times 5-6,5$ $\mathrm{mm}$, oblanceoladas, marrons.

Material examinado: Serra Talhada, PEMP, Açude do Saco, 7.XI.1993, fl., F. Gallindo et al. (IPA-55078); Serra Grande, 12.VII.1990, fl., R. Pereira et al. 382 (IPA).

Material adicional: Santa Cruz da Baixa Verde, Olho d'água, Serra da Madeira, fr., S.S. Matos et al. 115 (HESBRA); 8.VIII.2013, fr., M.G. Almeida 2 (HESBRA).

Espécie encontrada no Brasil, Bolívia, norte da Argentina e no Paraguai (Lewis et al. 2005). No Brasil, está presente no Nordeste (Alagoas, Bahia, Ceará, Paraíba, Pernambuco, Rio Grande do Norte e Sergipe), Centro-Oeste (Mato Grosso do Sul, Mato Grosso), todos os estados do Sudeste e do Sul, nos domínios Caatinga, Cerrado e Atlântico, em áreas antropizadas, Floresta estacional decidual, Floresta estacional semidecidual e Floresta ombrófila (Carvalho et al. 2016). No PEMP foi encontrada em locais antropizados.

Pterogyne nitens é a única espécie de Caesalpinioideae da área de estudo que apresenta folhas imparipinadas, pétalas pequenas $(2-2,6 \mathrm{~mm}$ compr. vs. 2,6-32 mm compr. das demais espécies) e fruto do tipo sâmara.

Floresce e frutifica em abril e agosto.

\section{Senna Mill.}

Senna possui cerca de 300 espécies e distribuição pantropical (Lewis et al. 2005). No Brasil, são encontradas cerca de 80 espécies ocorrendo em todas as regiões e estados do país, nos domínios Amazônico, Caatinga, Cerrado, Atlântico, Pampa e Pantanal, em todas as formações vegetacionais (BFG 2018). É o gênero de Caesalpinioideae com maior riqueza de espécies do PEMP.

Pode ser diagnosticado pelas flores amarelas, usualmente assimétricas, enantiostílicas, sem brácteas no pedicelo, com androceu heteromórfico e anteras basifixas, bem como folhas comumente com nectários entre os pares de folíolos e frutos predominantemente indeiscentes (Irwin \& Barneby 1982). 


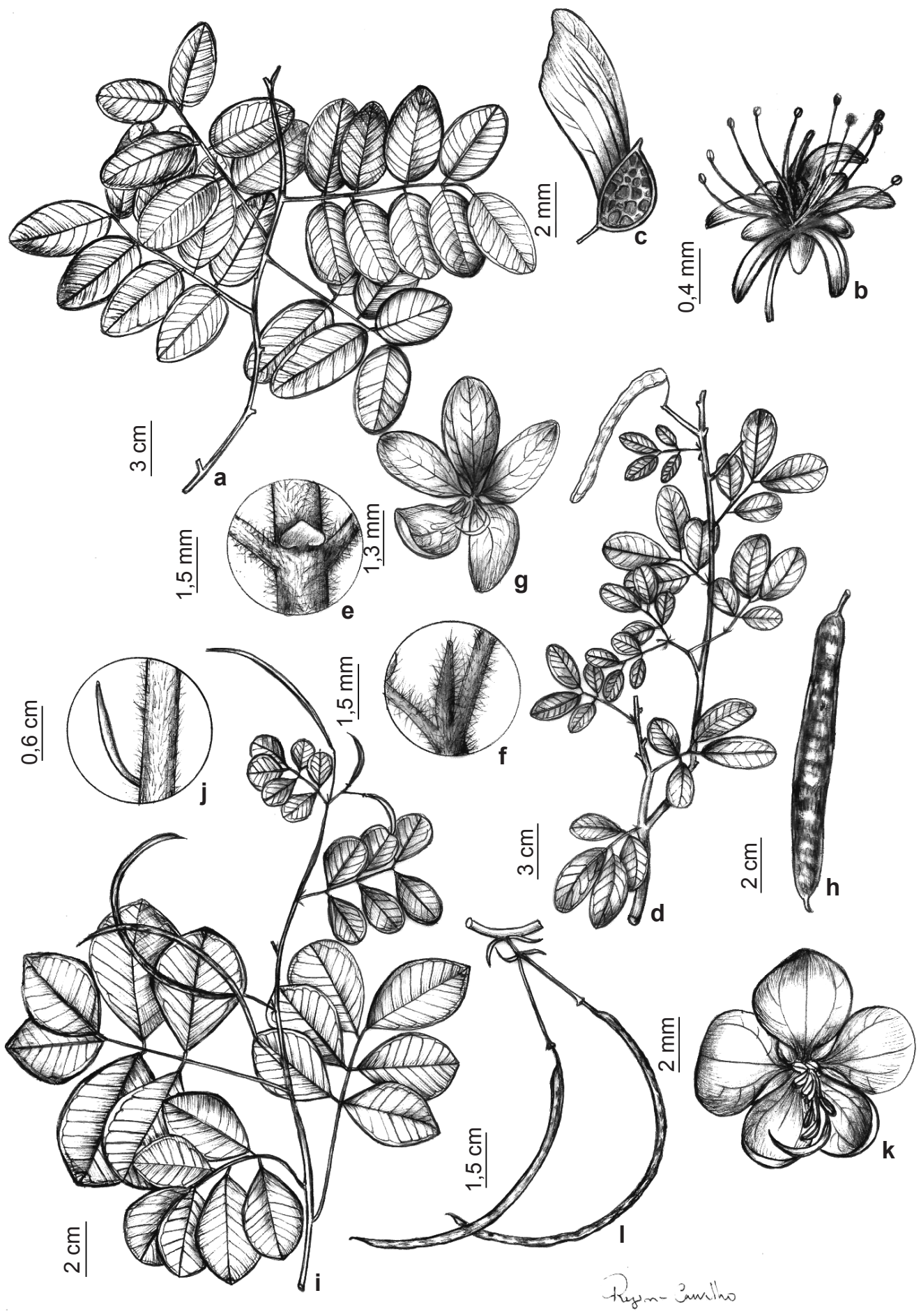

Figura 5 - a-c. Pterogyne nitens - a. ramo; b. flor; c. fruto. d-h. Senna macranthera - d. ramo; e,f. detalhe do nectário extrafloral e do indumento; g. flor; h. fruto. i-1. Senna obtusifolia - i. ramo; j. nectário extrafloral na raque; k. flor; 1. fruto. (a-c. F. Gallindo et al. (IPA-55078); S.S. Matos et al. 115; d-h. T.G.C. Menezes et al. 85; i-1. K.R. Miranda et al. $4 b)$.

Figure 5 - a-c. Pterogyne nitens - a. branch; b. flower; c. fruit. d-h. Senna macranthera - d. branch; e,f. detail of the extrafloral nectary and the indumentum; g. flower; h. fruit. i-1. Senna obtusifolia - i. branch; j. detail of the extrafloral nectary; k. flower; 1. fruit. (a-c. F. Gallindo et al. (IPA-55078); S.S. Matos et al. 115; d-h. T.G.C. Menezes et al. 85; i-1. K.R. Miranda et al. 4b). 
7.1. Senna macranthera (DC. ex Collad.) H.S. Irwin \& Barneby, Mem. New York Bot. Gard. 35: 181. 1982.

Figs. 1j; 5d-h

Arbustos 2-4,5 m alt.; ramos cilíndricos a achatados, castanhos a acinzentados, pubescentes a tomentosos, indumento creme, sem lenticelas. Estípulas 3-7 × 0,25-1 $\mathrm{mm}$, triangulares, pubescentes; pecíolo canaliculado a subcilíndrico, 0,4-2 cm compr., tomentoso, nectário ausente. Folhas paripinadas, folíolos 4, livres; lâmina foliar 24-86 × 9-42 mm, elíptica a oboval, base oblíqua, ápice arrredondado a obtuso mucronado, margem ciliada, face abaxial tomentosa, adaxial pubescente, nervura primária cêntrica, secundárias de menor calibre, proeminentes na face abaxial e impressas na face adaxial, raque $0,5-1,3 \mathrm{~cm}$ compr., tomentosa, canaliculada, nectário 1 , entre o par proximal ou em ambos os pares de folíolos, digitiformes, estipe largo. Panícula ou racemo, terminal ou axilar, 6,2-10,1 cm compr., nectário ausente; pedúnculo 1,5-5 cm compr., tomentuloso; bractéola 5-7,5 $\times 0,5-1 \mathrm{~mm}$, triangular, tomentosa, na base do pedicelo, persistente; sépalas 6-9 $\times$ $2,7-5,5 \mathrm{~mm}$, discretamente desiguais, lanceoladas a lanceovadas, pubescentes, verde-amareladas; pétalas $6,5-7,5 \times 3,4 \mathrm{~mm}$, equilongas, tomentosas, espatuladas, hipanto ausente, filete 1-2 mm compr., estames 6-7, heterodínamos, 2 ou 3 maiores, 3 ou 4 menores, anteras 5-10 mm compr., heteromórficas, maiores rostradas, menores não rostradas, oblongas, achatadas, poricidas, estaminódios 1-3, espatulados; ovário 5,2 mm compr., seríceo, densamente setoso, oblongo. Legume bacoide, 7,5-13 × 0,4-1,2 cm, estreitamente oblongo, tomentoso, marrom escuro. Sementes 2,4-3 × 1-1,3 mm, orbiculares, castanhoescuras.

Material examinado: Serra Talhada, Estação Experimental do IPA - Lauro Bezerra, Pimenteira, 19.V.2010, fl. e fr., T.G.C. Menezes et al. 85 (HESBRA); 6.VII.2011, fl. e fr., N.T. Rodrigues-Santos et al. 1 (HESBRA); 1.IV.2012, fl., F. Vieira da Silva 67 (HESBRA); PEMP, Campus UAST, 21.V.2010, fl. e fr., G.P. Silva 79 (HESBRA).

Espécie sul-americana presente na Bolívia, Brasil, Peru e Venezuela (Irwin \& Barneby 1982). Em território nacional, é encontrada nas regiões Norte (Tocantins), Nordeste (Alagoas, Bahia, Ceará, Paraíba, Pernambuco, Piauí, Rio Grande do Norte), Centro-Oeste (Distrito Federal, Goiás, Mato Grosso), em todos os estados da região Sudeste e no Sul (Paraná), nos domínios Caatinga, Cerrado e Atlântico, ocorre em áreas antropizadas, Caatinga stricto sensu, Carrasco, Cerrado lato sensu, Floresta ciliar e Floresta ombrófila (BFG 2018). Tem ampla distribuição no PEMP, em áreas planas e sobre serras, em solos argilo-arenosos e em afloramentos rochosos.

Assemelha-se a Senna splendida por compartilhar as folhas com quatro folíolos e o tamanho e forma da lâmina foliar. Entretanto, estas espécies podem ser diferenciadas pelo indumento pubescente a tomentoso nos ramos (vs. ramos glabros em $S$. splendida), pétalas menores 6,5-7,5 $\times 3,4 \mathrm{~mm}$ e frutos também 7,5-13 $\times 0,4-1,2 \mathrm{~cm}$ em S. macranthera (vs. pétalas maiores 29-32 × 18-19 $\mathrm{mm}$, e frutos $21,3-30,9 \times 0,4-1,2 \mathrm{~cm}$ ).

Floresce de março a maio e frutifica em maio.

7.2. Senna obtusifolia (L.) H.S. Irwin \& Barneby, Mem. New York Bot. Gard. 35:252. 1982.

Fig. 5i-1

Ervas a subarbustos 0,4-1 m alt.; ramos cilíndricos a estriados, verdes, glabros, sem lenticelas. Estípulas 7-13 × 0,5-1 mm, lanceoladas, pubérulas; pecíolo canaliculado, 1,5-4,5 cm compr., pubérulo, nectário ausente. Folhas paripinadas, folíolos 6, lâmina foliar 16-67 × 11-34 mm, oboval, base oblíqua a obtusa, ápice arrredondado a obtuso apiculado, margem ciliada, face abaxial pubescente, adaxial glabra, nervura primária cêntrica, secundárias de menor calibre, discretas em ambas as faces, raque $0,9-3,3 \mathrm{~cm}$ compr. não transformada em espinho, pubérula, canaliculada, nectário 1, entre o par proximal de folíolos, digitiformes. Racemo, terminal ou axilar, 2,5-3,5 cm compr., nectário ausente; pedúnculo $0,7-2,9 \mathrm{~cm}$ compr., pubescente; bractéola 5-6 × 0,7-0,8 $\mathrm{mm}$, linear, pubescente, na base do pedicelo, persistente; sépalas 4-8 × 2,5-4,5 $\mathrm{mm}$, discretamente desiguais, lanceoladas a lanceoladas, pubescentes, verdes; pétalas $6,5-8 \times 5-6 \mathrm{~mm}$, subequilongas, pubescentes, lanceoladas, hipanto ausente, filete 1,5-2,1 mm compr., estames 7, heterodínamos, 3 maiores, 4 menores, anteras 2,2-3,5 $\mathrm{mm}$ compr., heteromórficas, maiores rostradas, menores não rostradas, oblongas, cilíndricas, poricidas, estaminódios 3, filiformes ou craviforme; ovário 11 $\mathrm{mm}$ compr., seríceo, densamente setoso. Legume $2,9-15 \times 0,2-0,4 \mathrm{~cm}$, linear, pubérulo, verde, valvas plano-compressas. Sementes imaturas.

Material examinado: Serra Talhada, PEMP, IV.2011, fl., T.G.C. Menezes 259 (HESBRA); Lagoa Pimenteira II, 14.IX.2011, fl., $W$. Cordeiro 37 (HESBRA); lagoa na Estrada para o IPA, 21.VII.2008, fl. e fr., K.R. Miranda et al. 4b (HESBRA); próximo ao Açudezinho, 9.VI.2016, fl. e fr., W. Martins 2 (HESBRA). 
Distribui-se na América tropical desde o México até a Argentina e também na África e Ásia tropicais (Irwin \& Barneby 1982). Ocorre em todas as regiões e quase todos os estados do Brasil, exceto no extremo sul (Rio Grande do Sul, Santa Catarina). É encontrada nos domínios fitogeográficos Amazônico, Caatinga, Cerrado, Atlântico e Pantanal, em áreas antropizadas, campo limpo, Floresta de terra firme, Floresta ombrófila (BFG 2018). No PEMP é observada principalmente em áreas perturbadas, em borda de fragmentos e margens de estradas, em solos areno-argilosos.

Entre as espécies do PEMP, de um modo geral, Senna obtusifolia pode ser confundida com $S$. uniflora por ambas compartilharem o mesmo tipo de hábito e o mesmo número de folíolos e também pela ocorrência em ambientes semelhantes. Entretanto, estas espécies podem ser diferenciadas pelo maior tamanho da lâmina foliar em S. obtusifolia (16-67 $\times$ 11-34 mm vs. 8-43 × 8-14 mm em S. uniflora), por apresentar ramos glabros (vs. ferrugíneos nos ramos e frutos em $S$. uniflora).

Floresce e frutifica praticamente por todo o ano, exceto entre outubro e janeiro que corresponde ao período de estiagem na região.

Nome popular: mata pasto verdadeiro.

7.3. Senna occidentalis (L.) Link, Handbuch 2: 140. 1829.

Fig. 6a-d

Subarbustos eretos ca. $0,70 \mathrm{~m}$ alt.; ramos verdes, cilíndricos, glabros, sem lenticelas. Estípulas ca. $6 \times 1 \mathrm{~mm}$, triangulares, glabras; pecíolo achatado, 2,7-5,9 cm compr., glabro, nectário 1, na base do pecíolo próximo ao pulvino, globoso-côncavo. Folhas paripinada, folíolos 8; lâmina foliar 33-62 × 18-20 mm, lanceolada a elíptica, base oblíqua, ápice acuminado, margem ciliada, glabra em ambas as faces, raque $3,2-5 \mathrm{~cm}$ compr., não transformada em espinho, glabra a pubérula, canaliculada, nectário ausente. Racemo, terminal. Flores não observadas. Legume 9,3-12 $\times 0,5-0,8 \mathrm{~cm}$, pubérulo, faixa central marrom, lateral verde, estreitamente oblongo, faixa central marrom, lateral verde, valvas elásticas. Sementes não observadas.

Material examinado: Serra Talhada, PEMP, Estação Experimental do IPA - Lauro Bezerra, Vila saco, 22.III.1996, fl., M.L. Gomes et al. 174 (IPA).

Material adicional: Mirandiba, Areia Molhada, 21.VI.2007, fl., E. Córdula et al. 296 (UFP). Petrolina, Fazenda Perpétua, 25 km para Afrânio, 6.I.1961, fl. e fr., Andrade-Lima 3614 (IPA).

Espécie com ampla distribuição na América tropical e subtropical, África, Ásia e Austrália (Irwin
\& Barneby 1982). Ocorre no Brasil em todas as regiões e estados, nos domínios fitogeográficos Amazônico, Caatinga, Cerrado, Atlântico e Pantanal (BFG 2018). Na área de estudo, é raramente encontrada e está associada a ambientes perturbados próximos a corpos d'água, em solos arenosos e lodosos.

Senna occidentalis se distingue das outras espécies do gênero por ser a única a apresentar folíolos lanceolados a elípticos e nectário globoso e côncavo na base do pecíolo próximo ao pulvino. Floresce em março.

7.4. Senna spectabilis (DC.) H.S. Irwin \& Barneby, Mem. New York Bot. Gard. 35: 600. 1982.

Fig. 6e-g

Arbusto a árvore ca. 4,5 m alt.; ramos verdes a castanhos, cilíndricos, tomentosos, indumento creme, lenticelas circulares a elípticas, cremes, esparsadas. Estípulas $8-10 \times 0,5-0,8 \mathrm{~mm}$, triangulares, tomentosas; pecíolo canaliculado, 1,7-2,4 cm compr., tomentoso, nectário ausente; paripinada, 20-22 folíolos, opostos; lâmina foliar 18-40 × 10-19 mm, elíptica, base oblíqua, ápice agudo apiculado, margem ciliada, face abaxial pubescente, adaxial pubescente, nervura primária cêntrica, secundárias de menor calibre, proeminentes na face abaxial e impressas na face adaxial, raque 10,2-14,5 cm compr., não transformada em espinho, tomentoso, canaliculada, nectário ausente. Panícula, terminal, 3,2-15,1 cm compr., nectário ausente; pedúnculo $0,9-5,5 \mathrm{~cm}$ compr., tomentuloso, bractéola 4-6 × 2-2,8 $\mathrm{mm}$, lanceolada, tomentosa, uma, na base do pedicelo, caduca; sépalas $2,2-8,5$ $\times 5,1-11 \mathrm{~mm}$, fortemente desiguais, três maiores e duas menores, suborbiculares, puberulentas a pubescentes, amarelas; pétalas 13-29 × 14-19 $\mathrm{mm}$, desiguais, assimétricas, glabras, lateral maior subreniforme, obovais, hipanto ausente; filete 4-10 $\mathrm{mm}$ compr., estames 7 , levemente heterodínamos, anteras 7,4-8,0 $\mathrm{mm}$ compr., homomórficas, não rostradas, oblongas, cilíndricas, poricidas, estaminódios 3, reniformes; ovário 18-25 mm compr., glabro, oblongo. Legume bacoide, 11-30 $\times 0,8-1 \mathrm{~cm}$, estreitamente oblongoide, glabro, marrom escuro. Sementes 4,8-6,5 × 4,5-5 mm, largamente ovoides, marrons.

Material examinado: Serra Talhada, PEMP, Estação Experimental do IPA - Lauro Bezerra, 22.III.2010, fl., T.G.C. Menezes et al. 64 (HESBRA); Serra Branca, 12.I.2011, fl., R.S. Cordeiro 193 (HESBRA).

Material adicional: Santa Cruz da Baixa Verde, Olho d'Água, Serra da Madeira, 3.VIII.2013, fl. e fr., $L$. 


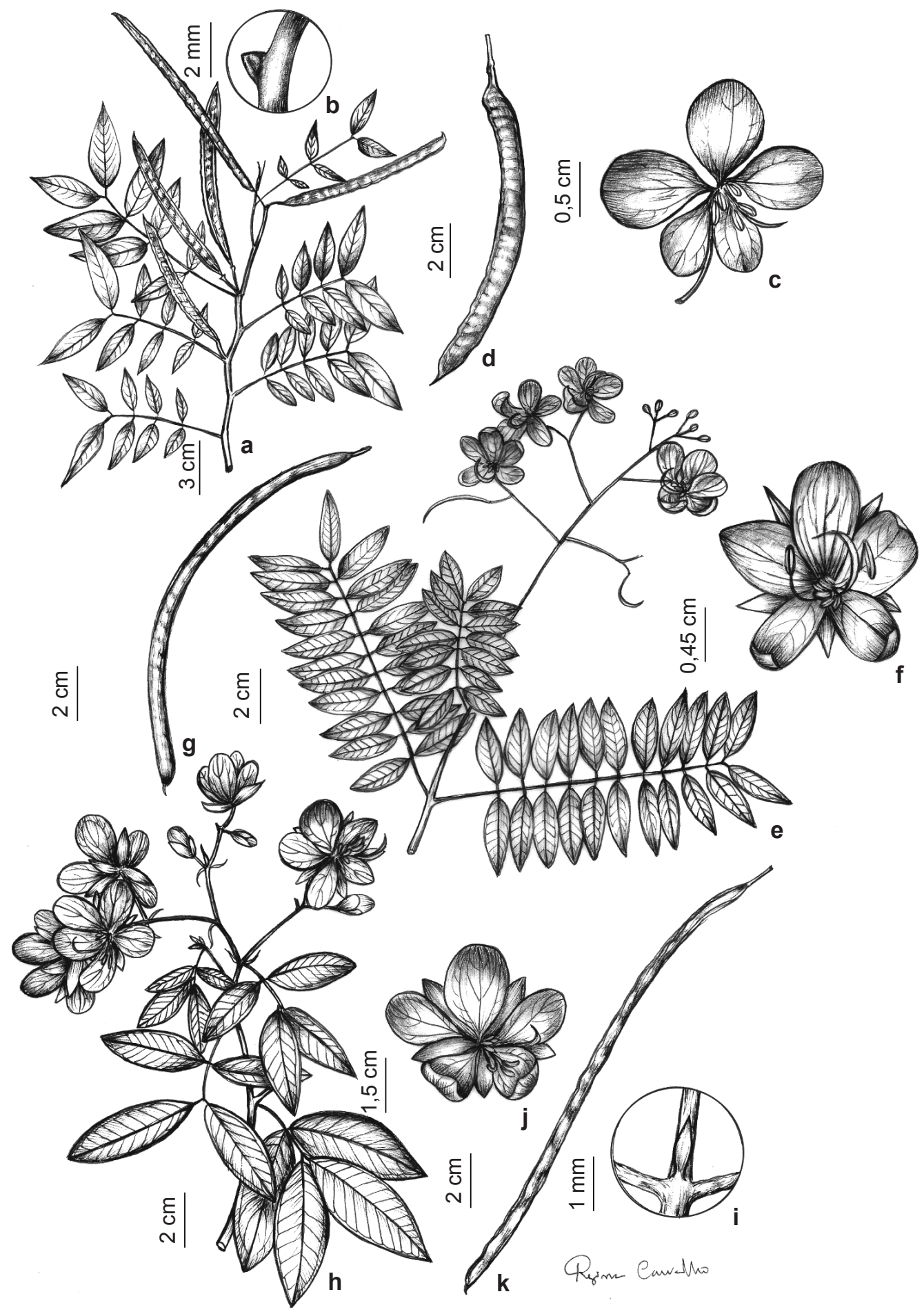

Figura 6 - a-d. Senna occidentalis - a. ramo; b. detalhe da posição do nectário extrafloral; c. flor; d. fruto. e-g. Senna spectabilis - e. ramo; f. flor; g. fruto. h-k. Senna splendida - h. ramo; i. detalhe da posição do nectário extrafloral; j. flor; k. fruto. (a-d. M.L. Gomes et al. 174; T.G.C. Menezes et al. 64; L. Maciel-Júnior et al. 16; h-k. E.S.S. Silva et al. 21). Figure 6 - a-d. Senna occidentalis - a. branch; b. detail of the position of the extrafloral nectary; c. flower; d. fruit. e-g. Senna spectabilis - e. branch; f. flower; g. fruit. h-k. Senna splendida - h. branch; i. detail of the position of the extrafloral nectary; j. flower; k. fruit. (a-d. M.L. Gomes et al. 174; T.G.C. Menezes et al. 64; L. Maciel-Júnior et al. 16; h-k. E.S.S. Silva et al. 21). 
Maciel-Júnior et al. 16 (HESBRA); 6.X.2015, fl. e fr., M.A.I. Lima 2 (HESBRA); Triunfo, próximo ao SESC, 28.III.2015, fl., L. Maciel-Júnior 402 (HESBRA).

Espécie distribuída no México, América Central, norte da América do Sul até Argentina, Bolívia e Paraguai, incluindo os Andes (Irwin \& Barneby 1982). No Brasil, está presente na região Norte (Acre, Pará, Tocantins), em todo o Nordeste e Centro-Oeste e no Sudeste (Minas Gerais), nos domínios Amazônico, Caatinga, Cerrado e Atlântico, áreas antropizadas, Caatinga stricto sensu, Cerrado lato sensu, Floresta de terra firme e Floresta ombrófila (BFG 2018). Apresenta ampla distribuição no PEMP sendo observada, desde áreas planas até o topo da Serra Talhada (ca. $800 \mathrm{~m}$ de altitude), em áreas preservadas e perturbadas, sendo cultivada ainda no Campus da Unidade Acadêmica de Serra Talhada, na área de amortecimento do parque. Ocorre sobre solos argilo-arenosos, pedregosos e sobre afloramentos rochosos.

Senna spectabilis distingue-se das demais espécies de gênero ocorrentes no PEMP por apresentar, folhas multijugas com mais de 8 folíolos, sem nectários, flores assimétricas e pétalas grandes $(13-29 \times 14-19 \mathrm{~mm})$.

Floresce em março e frutifica de janeiro a outubro.

Nome popular: canafístula.

7.5. Senna splendida (Vogel) H.S. Irwin \& Barneby, Mem. New York Bot. Gard. 35: 190. 1982.

Figs. 1j; 6h-k

Arbustos 2-4 m alt.; ramos verdes, cilíndricos, glabros, sem lenticelas. Estípulas 15-17 × 2,8-3 $\mathrm{mm}$, lanceoladas, glabras; pecíolo canaliculado, 0,8-2,1 cm compr., glabro, nectário ausente. Folhas paripinadas, folíolos 4; lâmina foliar 16-85 × 9-34 $\mathrm{mm}$, estreitamente elíptica, base cordada a oblíqua, ápice agudo, margem inteira, face abaxial e adaxial glabra, nervura primária cêntrica, secundárias de menor calibre, proeminentes em ambas as faces, raque $0,5-1,5 \mathrm{~cm}$ compr., não transformada em espinho, glabra a pubérula, canaliculada, nectário 1 , entre cada par de folíolos, digitiformes, estipe estreito. Panícula ou racemo, axilar ou terminal, 2-7,5 cm compr., nectário ausente; pedúnculo 1,3-2,5 cm compr., glabra; bractéola 7-8,5 × 1,5-2 mm, lanceolada, glabra, uma, na base do pedicelo, persistente; sépalas 20-30 × 8-14 mm, discretamente desiguais, lanceoladas, glabras, marrom-amareladas; pétalas 29-32 × 18-19 mm, pubérulas, obovais, hipanto ausente; filete 0,7-2,2 mm compr., estames 7, heterodínamos, 2 maiores,
5 menores, anteras 6-18 mm, homomórficas, todas rostradas, oblongas, cilíndricas, poricidas, estaminódios 3, espatulados; ovário 34-40 mm compr., seríceo, densamente setoso, oblongo; Legume bacoide, 21,3-30,9 × 0,4-1,2 cm, linear, glabro, marrom. Sementes imaturas.

Material examinado: Serra Talhada, PEMP, entrada do Campus UAST, 2.IX.2008, fl. e fr., E.S.S. Silva et al. 21 (HESBRA); Vila Saco, 21.V.1996, fl., M.L. Gomes et al. 224 (IPA).

No Brasil ocorre nas regiões Nordeste (Alagoas, Bahia, Ceará, Paraíba, Pernambuco, Piauí, Rio Grande do Norte, Sergipe), Centro-Oeste (Mato Grosso do Sul), em todos os estados do Sudeste e no Sul (Paraná), nos domínios Caatinga stricto sensu, Cerrado lato sensu, Floresta ciliar, Floresta ombrófila e Restinga (BFG 2018). No PEMP, são encontrados alguns indivíduos isolados dessa espécie, geralmente em locais preservados em solo argilo-arenosos ou sobre afloramentos rochosos, em altitudes que variam 500 a $800 \mathrm{~m}$.

Senna splendida compartilha características semelhantes a $S$. macranthera como as folhas com quatro folíolos e o tamanho e forma da lâmina foliar. Os caracteres diagnósticos entre estas espécies estão apresentados nos comentários de $S$. macranthera.

Floresce e frutifica em setembro.

7.6. Senna uniflora (Mill.) H.S. Irwin \& Barneby, Mem. New York Bot. Gard. 35: 258. 1982.

Fig. $7 \mathrm{a}-\mathrm{d}$

Ervas a subarbustos $0,5-0,7 \mathrm{~m}$ alt.; ramos cilíndricos, verde-claros, tomentosos, indumento ferrugíneo, sem lenticelas. Estípulas 8-18 $\times$ 0,7-1 mm, estreitamente-triangulares, tomentosas, persistentes; pecíolo canaliculado, 1-2,2 cm compr., tomentoso, nectário ausente. Folhas paripinadas, folíolos 6-8, livres, lâmina foliar 8-43 $\times$ 8-14 mm, obovais a elípticas, base oblíqua, ápice agudo apiculado, margem ciliada, face abaxial serícea, adaxial serícea, nervura primária cêntrica, secundárias de menor calibre, proeminentes na face abaxial e discretas na face adaxial, raque 1,7-4,3 cm compr., não transformada em espinho, tomentoso, canaliculada, nectário 1 , entre cada um dos pares de folíolos, digitiformes, estipe estreito. Racemo, axilar, ca. 1,3 cm compr., nectários digitiformes no eixo principal; pedúnculo 0,7-1,2 cm compr., seríceo; bractéola $8-9,5 \times 0,6-0,8$ $\mathrm{mm}$, linear, tomentosa, uma, na base do pedicelo, caduca; sépalas ca. 3,1 × 1,2 mm, discretamente desiguais, obovais, seríceas, verdes; pétalas 5,1-5,3 
$\times 2,8-3,5 \mathrm{~mm}$, equilongas, glabras, espatuladas, hipanto ausente, filete 1,4-2,1 mm compr., estames 7, heterodínamos, 2 maiores, 5 menores, anteras 1,2-2,1 mm compr., homomórficas, todas rostradas, oblongas, cilíndricas, poricidas, estaminódios 3, espatulados; ovário 5-6,5 mm compr., seríceo, densamente setoso ferrugíneo. Legume $1-5 \times$ 0,2-0,35 cm, linear, valvas elevadas na região da semente, tomentoso, róseo-ferrugíneo. Sementes 2-3 $\times 2,5-3,3 \mathrm{~mm}$, oblongas, verdes a marrons.

Material examinado: Serra Talhada, Estação Experimental do IPA - Lauro Bezerra, Pimenteira, 4.IV.2010, fl., T.G.C. Menezes et al. 78 (HESBRA); PEMP, Campus UAST, 11.V.2010, fl. e fr., G.P. Silva et al. 71 (HESBRA); próximo ao Açudezinho, 9.VI.2016, fl. e fr., W.C. Novaes 2 (HESBRA).
Espécie com distribuição no México, América Central e Brasil (Irwin \& Barneby 1982). Ocorre na Região Norte (Roraima), em todos os estados do Nordeste, Centro-Oeste (Goiás) e Sudeste (Minas Gerais, São Paulo) do Brasil, nos domínios Amazônico, Caatinga e Cerrado, áreas antropizadas, Caatinga stricto sensu, Cerrado lato sensu, Floresta de terra firme (BFG 2018). Tem ampla distribuição em áreas planas do PEMP, no sub-bosque de áreas preservadas, mas também em ambientes perturbados como beiras de estrada, geralmente está associada à solos areno-argilosos.

Senna uniflora se assemelha morfologicamente a S. obtusifolia por compartilharem o mesmo tipo de hábito herbáceo a subarbustivo e o mesmo

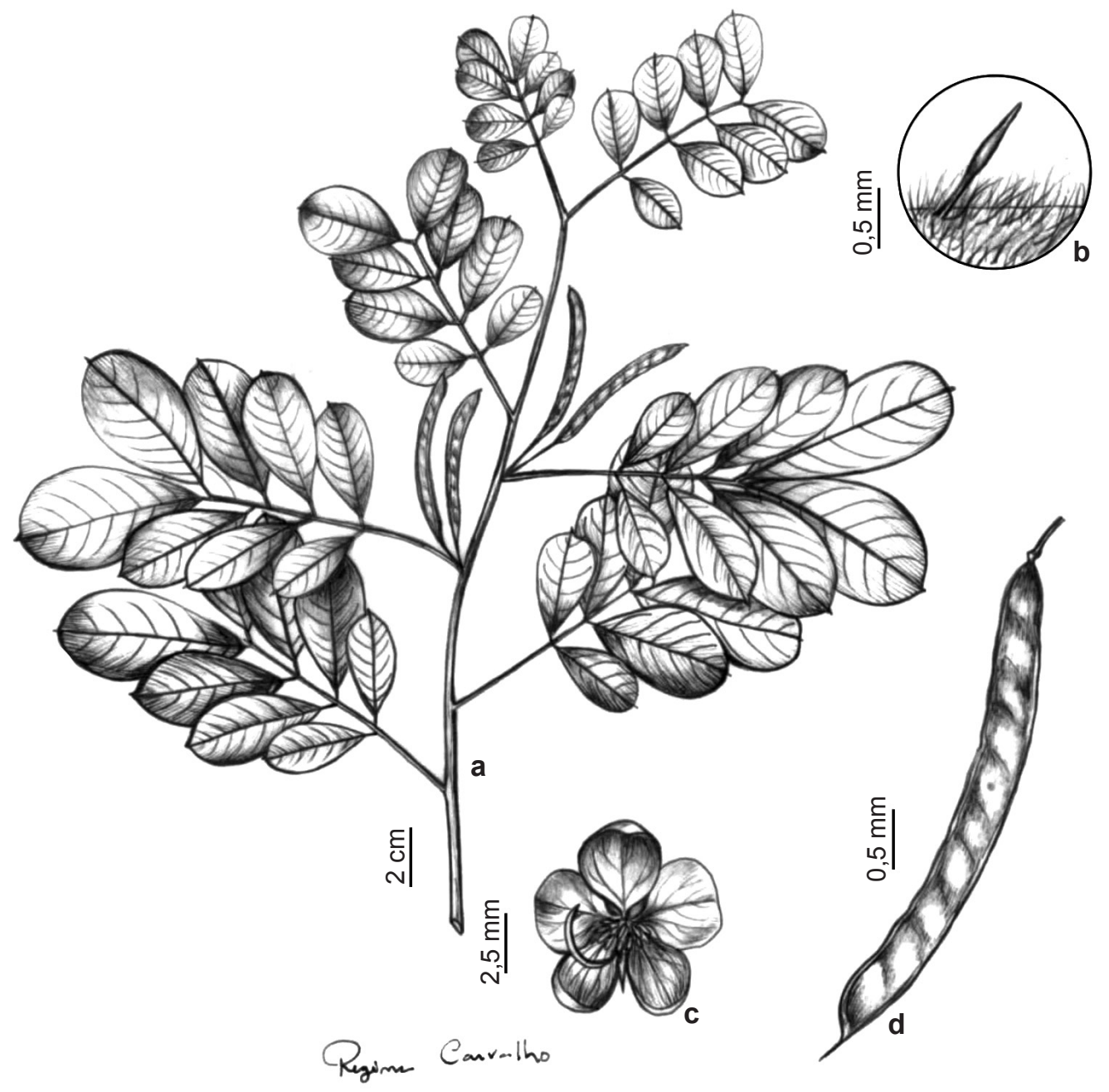

Figura 7 - a-d. Senna uniflora - a. ramo; b. detalhe do nectário extrafloral e do indumento; c. flor; d. fruto. (a-d. G.P. Silva et al. 71).

Figure 7 - a-d. Senna uniflora - a. branch; b. detail of the extrafloral nectary and the vestiture; c. flower; d. fruit. (a-d. G.P. Silva et al. 71). 
número de folíolos, além da presença em ambientes semelhantes. As características que distinguem estas duas espécies foram apresentadas nos comentários de Senna obtusifolia.

Floresce e frutifica de abril a junho.

\section{Agradecimentos}

À Coordenação de Aperfeiçoamento de Pessoal de Nível Superior - CAPES, a concessão de bolsa de Mestrado à primeira autora; aos curadores e aos técnicos dos Herbários visitados, a atenção e acolhimento durante a consulta das coleções; à Universidade Federal Rural de Pernambuco, Unidade Acadêmica de Serra Talhada, o suporte laboratorial e o auxílio nas coletas; em especial aos componentes do HESBRA, a ajuda em todas as etapas do estudo; a Rodolfo Araújo, o mapa geográfico da área estudada e a Regina Carvalho, as ilustrações.

\section{Referências}

Barroso GM, Morim MP, Peixoto AL \& Ichaso CLF (1999) Frutos e sementes: morfologia aplicada à sistemática de dicotiledôneas. Editora UFV, Viçosa. $443 p$.

Bentham G (1859) Leguminosae, Papilionaceae. In: Martius CFP (ed.) Flora Brasiliensis. Vol. 15. Leipzig, Munchen, Wien. Pp. 1-350.

Bentham G (1870) Leguminosae II. Swartzieae et Caesalpinieae. In: Martius CFP (ed.) Flora Brasiliensis. Vol. 15. Leipzig, Munchen, Wien. Pp. 1-254.

BFG - The Brazil Flora Group (2018) Brazilian Flora 2020: innovation and collaboration to meet Target 1 of the Global Strategy for Plant Conservation (GSPC). Rodriguésia 69: 1513-1527.

Campanha MM \& Araújo FS (2010) Árvores e arbustos do sistema agrossilvipastoril Caprinos e Ovinos. Embrapa Caprinos e Ovinos, Sobral. Pp. 32. (Documentos, 96).

Carvalho DAS, Rando JG \& Silva TS (2016) Pterogyne in Flora do Brasil 2020 em construção. Instituto de Pesquisas Jardim Botânico do Rio de Janeiro. Disponível em <http://floradobrasil.jbrj.gov.br/ reflora/floradobrasil/FB28161>. Acesso em 23 agosto 2016.

Doyle JJ, Chappill JA, Bailey CD \& Kajita T (2000) Towards a comprehensive phylogeny of Legumes: evidence from rbcL sequences and non-molecular data. In: Herendeen PS \& Bruneau A (eds.) Advances in Legume Systematics, part 9. Royal Botanic Gardens, Kew. Pp. 299-310.

Farias SGG, Rodal MJN, Melo AL, Silva MAM \& Lima ALA (2016) Fisionomia e estrutura de vegetação de Caatinga em diferentes ambientes em Serra
Talhada - Pernambuco. Ciência Florestal, Santa Maria 26: 435-448.

Flora do Brasil 2020 em construção. Instituto de Pesquisas Jardim Botânico do Rio de Janeiro. Disponível em <http://floradobrasil.jbrj.gov.br/ reflora/floradobrasil/FB22811>. Acesso em 1 dezembro 2016.

Gagnon E, Bruneau A, Hughes CE, Queiroz LP \& Lewis GP (2016) A new generic system for the pantropical Caesalpinia group (Leguminosae). PhytoKeys 71: 1-160.

Irwin HS \& Barneby RC (1982) The American Cassinae, a synoptical revision of Leguminosae, Tribe Cassieae, subtribe Cassinae in the New World. Memoires of the New York Botanical Garden 35: $1-918$.

Köppen W (1948) Climatologia: con un studio de los climas de la tierra. $1^{a}$ edición em español. Fondo de Cultura Económica, México. 478p.

Lewis GP (1987) Legumes of Bahia. Royal Botanic Gardens, Kew. Pp. 1-369.

Lewis GP, Schrire B, Mackinder B \& Lock M (2005) Legumes of the world. Royal Botanic Gardens, Kew. 577p.

Lewis GP (2005) Cassieae. In: Lewis GP, Schrire B, Mackinder B \& Lock M (eds.) Legumes of the world. Royal Botanic Gardens, Kew. Pp. 111-125.

LPWG - The Legume Phylogeny Working Group (2017) A new subfamily classification of the Leguminosae based on a taxonomically comprehensive phylogeny. Taxon 66: 44-77.

Melo Y, Córdula E, Machado SR \& Alves M (2010) Morfologia de nectários em Leguminosae senso lato em áreas de caatinga no Brasil. Acta botanica brasilica 24: 1034-1045.

Melo AL, Lima ALA, Menezes TGC, Cordeiro RS, Santos ES, Farias SGG, Silva FV, Caldas DRM, Matos SS, Melo R, Lima LR, Cordeiro WPS, Gomes APS \& Rodal MJN (2013) Flora vascular terrestre. In: Santos EM, Melo-Júnior M, Silva-Cavalcanti JS \& Almeida GVL (eds.) Parque Estadual Mata da Pimenteira: riqueza natural e conservação da Caatinga. EDUFRPE, Recife. Pp. 83-103.

Mori SA, Silva LAM, Lisboa G \& Coradin L (1989) Manual de manejo de herbário fanerogâmico. $2^{\mathrm{a}}$ ed. Centro de Pesquisa do Cacau, Ilhéus. 104p.

Polhill RM, Raven PH \& Stirton CH (1981) Evolution and systematics of the Leguminosae. In: Polhill RM \& Raven PH (eds.) Advances in Legume Systematics, part 1. Royal Botanic Gardens, Kew. Pp. 1-26.

Queiroz LP (2009) Leguminosas da Caatinga. Universidade de Feira de Santana, Feira de Santana. Pp. 1-467.

Queiroz RT \& Loiola MIB (2009) O gênero Chamaecrista Moench (Caesalpinoideae) em áreas do entorno do Parque Estadual das Dunas de Natal, Rio Grande do Norte, Brasil. Hoehnea 36: 725-736. 
Radford AE, Dickison WC, Massey R \& Bell CR (1974) Vascular plant systematics. Harper \& Row Publishers, Inc., New York. Pp. 1-891.

Romão MVV \& Mansano VF (2016) Parkinsonia in Flora do Brasil 2020 em construção. Instituto de Pesquisas Jardim Botânico do Rio de Janeiro. Disponível em $<$ http://floradobrasil.jbrj.gov.br/reflora/floradobrasil/ FB83554>. Acesso em 23 agosto 2016.

Santos EM, Almeida GVL, Oliveira, L.L.D.S.S.; Menezes, E.R.A.; Guedes, M.V.; Sacramento, A.N.; Bezerra, G.S.C.L.; Brito, J.V.A. \& Santos, J.C.O. 2013. Parque Estadual Mata da Pimenteira - Primeira Unidade de Conservação Estadual na Caatinga de Pernambuco. In: Santos, E.M.; Melo-Júnior, M.; Silva-Cavalcanti, J.S. \& Almeida, G.V.L. Parque Estadual Mata da Pimenteira: Riqueza Natural e Conservação da Caatinga. EDUFRPE, Recife. Pp. 15-26.

Silva TGF \& Almeida AQ (2013) Climatologia e características geomorfológicas. In: Santos EM, Melo-Júnior M, Silva-Cavalcanti JS \& Almeida GVL (eds.) Parque Estadual Mata da Pimenteira: riqueza natural e conservação da Caatinga. EDUFRPE, Recife. Pp. 29-36.

Simpson MG (2006) Plant systematics. Elsevier/ Academic Press, Amsterdam. 752p.

Thiers B [continuamente atualizado] Index Herbariorum: a global directory of public herbaria and associated staff. New York Botanical Garden's Virtual Herbarium. Disponível em $<$ http://sweetgum.nybg. org/science/ih/>. Acesso em 23 julho 2017.

Vaz AMSF \& Tozzi AMGA (2003) Bauhinia ser. Cansenia (Leguminosae: Caesalpinioideae) no Brasil. Rodriguésia 54: 55-143.

Wojciechowski MF (2003) Reconstructing the phylogeny of legumes (Fabaceae): an early $21^{\text {st }}$ century perspective. In: Klitgaard BB \& Bruneau A (eds.) Advances in Legume Systematics, part 10. Royal Botanic Gardens, Kew. Pp. 5-35.

Wojciechowski MF, Lavin M \& Sanderson MJA (2004) Phylogeny of Legumes (Leguminosae) based on analysis of the plastid matK gene resolves many well-suported subclades within the family. American Journal of Botany 91: 1846-1862. 